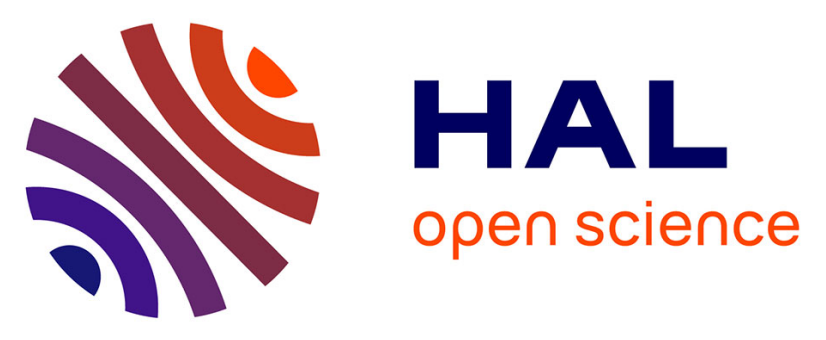

\title{
How to distinguish red coloring matter used in prehistoric time? The contribution of visible near-infrared diffuse reflectance spectroscopy
}

Emilie Chalmin, B Schmitt, Aurélie Chassin de Kergommeaux, Claire

Chanteraud, Fayçal Soufi, Hélène Salomon

\section{To cite this version:}

Emilie Chalmin, B Schmitt, Aurélie Chassin de Kergommeaux, Claire Chanteraud, Fayçal Soufi, et al. How to distinguish red coloring matter used in prehistoric time? The contribution of visible nearinfrared diffuse reflectance spectroscopy. Color Research and Application, 2021, 10.1002/col.22647 . hal-03150844

\section{HAL Id: hal-03150844 \\ https://hal-sde.archives-ouvertes.fr/hal-03150844}

Submitted on 30 Jul 2021

HAL is a multi-disciplinary open access archive for the deposit and dissemination of scientific research documents, whether they are published or not. The documents may come from teaching and research institutions in France or abroad, or from public or private research centers.
L'archive ouverte pluridisciplinaire HAL, est destinée au dépôt et à la diffusion de documents scientifiques de niveau recherche, publiés ou non, émanant des établissements d'enseignement et de recherche français ou étrangers, des laboratoires publics ou privés. 


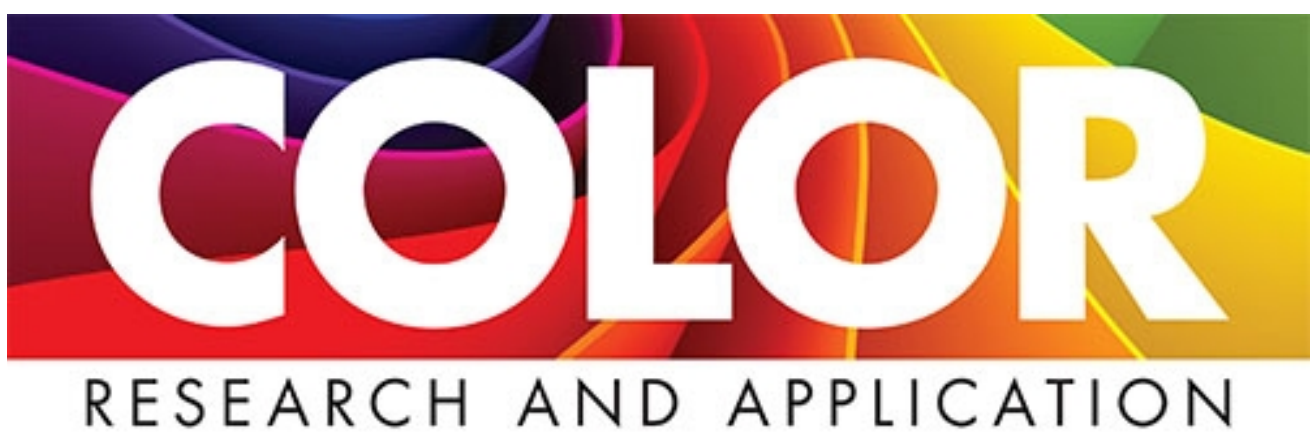

\section{How to distinguish red coloring matter used in prehistoric time? The contribution of visible near-infrared diffuse reflectance spectroscopy}

\begin{tabular}{|r|l|}
\hline Journal: & Color Research and Application \\
\hline Manuscript ID & COL-20-228.R1 \\
\hline Wiley - Manuscript type: & Research Article \\
\hline Date Submitted by the & $\mathrm{n} / \mathrm{a}$ \\
\hline Complete List of Authors: & $\begin{array}{l}\text { Chalmin, Emilie; Université Savoie Mont-Blanc, EDYTEM } \\
\text { Schmitt, Bernard; Université Grenoble Alpes, IPAG } \\
\text { Chassin de Kergommeaux, Aurélie; Université Savoie Mont-Blanc, } \\
\text { EDYTEM } \\
\text { Chanteraud, Claire; Université Savoie Mont-Blanc, EDYTEM } \\
\text { Soufi, Fayçal; Université Savoie Mont-Blanc, EDYTEM } \\
\text { Salomon, Hélène; Université Savoie Mont-Blanc, EDYTEM }\end{array}$ \\
\hline Keywords: & $\begin{array}{l}\text { Red coloring matter, Rock art, Diffuse reflectance, Prehistory, Visible- } \\
\text { infrared spectra }\end{array}$ \\
\hline &
\end{tabular}

\section{SCHOLARONE \\ Manuscripts}




\title{
How to distinguish red coloring matter used in prehistoric time? The contribution of visible near-infrared diffuse reflectance spectroscopy
}

\author{
Emilie Chalmin $^{1 *}$, Bernard Schmitt ${ }^{2}$, Claire Chanteraud ${ }^{1}$, Aurélie Chassin de Kergommeaux ${ }^{1}$, \\ Fayçal Soufi ${ }^{1}$ and Hélène Salomon ${ }^{1}$ \\ 1 Univ. Savoie Mont Blanc, CNRS, EDYTEM (UMR 5204), Le Bourget du Lac, France \\ 2 Univ. Grenoble Alpes, CNRS, IPAG (UMR 5274), Grenoble, France \\ *Corresponding author: emilie.chalmin-aljanabi@univ-smb.fr
}

\begin{abstract}
Although the main prehistoric color used for paintings is red, knowledge of this coloring matter often boils down to saying that it is "ochre". However, the red coloring matter of Prehistory is numerous and may have been the subject of various preparations, mixtures, or even alterations. Understanding the use and transformation of coloring matter raises questions about the technical processes but also about the supply strategies of these ancient societies. In the case of analysis of solid archaeological remains, we can access the petrography, mineralogy and chemistry of these ferruginous rocks. But when it is about deposited powder, the means of investigation become limited. We therefore propose to test the complementarity of spectro-radiometry, a non-invasive method that allows us to obtain a spectral signature of the material whatever its mode of preparation. From six geological reference samples chosen for their color (from red to yellow) and for their mineralogical composition, spectra in the visible and near-infrared were recorded under several experimental conditions and several modes of preparation of the matter, using two spectrogonio radiometers. It is then possible to discriminate these different coloring matter on the basis of their spectral signature and to understand the link with their mineral composition.
\end{abstract}

Keywords: red coloring matter, rock art, Prehistory, diffuse reflectance, visible-infrared spectra

\section{FUNDING INFORMATION}

Regional Archaeological Service of the Auvergne-Rhône-Alpes region: PCR Pigmentothèque, Fundings obtained in 2016, 2018, 2019 and 2020.

University of Savoie-Mont-Blanc: MASCARA (2017 and 2018) and TRAnSFeRT projects (2019)

Europlanet 2024 RI programme: European Union's Horizon 2020 research and innovation programme under grant agreement No 654208.

\section{INTRODUCTION}

Throughout prehistoric times, the most common color used to paint, draw or apply to different surfaces was red. This color comes from the use of various ferruginous rocks widely available in the landscape during this period. Although black is present on the drawings and paintings of prehistoric rock art as charcoal or manganese oxide, much less remains related to its exploitation and transformation have been found compared to red. Numerous remains of red coloring matter 
have been identified in the archaeological sequences. These coloring matters may be present in the form of cohesive raw blocks, crushed blocks or in transformed forms as powder, applied powder on various supports (bone, pearl or rock) and faceted or striated blocks. The presence of these coloring matters in large numbers in contexts as varied as settlement or rock art sites suggests that these coloring matters were used not only for their coloring properties, but also for other characteristics such as technical properties (e.g. hide processing, polishing) ${ }^{1,2,3}$.

Often misnamed as "ochre", these coloring matters found in archaeological contexts are of very varied mineralogical and geological nature, reflecting the diversity of geological formations accessible in the environment. Many questions remain to identify them, differentiate their origin, and understand their transformation.

The interest of studying prehistoric coloring matters lies in the fact that this type of artefacts recorded stigmata related to practices and techniques performed by past societies. It is indeed possible to (i) identify the methods of preparation (scraping, grinding, crushing, abrasion...), (ii) recognize the type of rocks exploited when they are still in the form of cohesive blocks or (iii) access their chemical composition which can be very informative in the presence of specific trace elements (e.g. ${ }^{4,5,6}$ ).

To characterize these archaeological remains, it is necessary to use a wide range of analytical methods at different scales of observation (macro, meso, micro), which may be invasive or may require the partial destruction of the object or microsampling. This characterization is more delicate in the case of powder deposited on a substrate, because powdering, mixing and/or alteration blur the characteristics of their provenance. Indeed, the evolution of the raw material in its geological context, during its preparation and after its burial (taphonomy) need to be considered (" chaîne évolutive " 7,8,9). Therefore, characterization of coloring matter does not necessarily enable the identification of the parent rock and thus of the trajectory of raw materials and/or that of the remains.

Red coloring raw materials could come from various types of ferruginous rock: (i) sedimentary processes: e.g. Banded Iron Formation (BIF), Oolithic Iron Stones (OIS), iron-rich sandstone; (ii) mineralisations: e.g. veins, lode, metasomatism; (iii) weathering processes: e.g. ochre, laterite, bauxite; volcanic and metamorphic processes. These various ferruginous rocks present various mechanical, physical, chemical and coloring properties ${ }^{10,11}$. Our collection has been undertaken to record and sample ferruginous rocks in different geological and geographical contexts, documenting the potential resources for the supply of raw ferruginous materials during Prehistory (from Palaeolithic to Neolithic) and even more recent historic periods.

Since 2016, more than two hundred outcrops of ferruginous rock mainly in the Ardèche and Gard valleys have been collected based on geological documentation and surveys. This region is particularly rich in Upper Palaeolithic rock art and settlement sites from the Middle Palaeolithic to the Neolithic containing artefacts of coloring matter, the use of which has not always been identified $12,13,14,10$.

This collection is the subject of a petrographic, mineralogical, chemical and physical description and analysis on various preparations (fresh cut, polished stud, sieved or unsieved powder) based on a shared vocabulary (lexicon) and a systematic documentation of the stigmata and characteristics of the rock samples which correspond to formation conditions, evolutions before and after selection by human groups. Although it is easy to link the red, orange and yellow colors 
with the presence of iron in the form of oxides (red hematite $\alpha-\mathrm{Fe}_{2} \mathrm{O}_{3}$ ) or oxyhydroxides (yellow goethite $\alpha-\mathrm{FeO}(\mathrm{OH})$ ), it is not so easy to compare the color of different materials or to access the sometimes complex mineralogical composition of these rocks. Colorimetric measurements or spectral measurements limited to the visible range make it possible to classify materials by color as can be done from charts such as the Munsell chart. The difficulty of such a determination lies in: (i) the potential variability of color within a rock (gradient or color zones, differences between external and internal colors), (ii) the texture of the material which leads either to a very dull material or to a material with metallic lustre, (iii) its texture (grain size and shape, porosity, ...) that can also modulate the color tone and is not taken into account in the color charts, (iv) the difficult access to a fresh cut of the material for archaeological objects, $(v)$ the variability of the spectral radiance of the illumination source used for the observation, (vi) the wide range of light absorption spectra of materials that can result in the same perceived color for different materials, (vii) the visual experience of the observer in the case of visual charts. The elaboration of a more objective and standardized method is required in order to give access not only to color but also to the structure and composition of the raw materials and transformed matters. Diffuse reflectance spectroscopy, which can scan over a wide spectral range from the visible to the mid-infrared, typically up to $0.3-5 \mu \mathrm{m}$ (e.g. ${ }^{15}$ ), offers the possibility to fully remove the last 3 limitations or bias ( $v$ to vii) and to objectively study the origin of the color variability and the effects of texture (points i to iii). This method has also the advantage of being non-contact, non-invasive and can be used on any type of sample (powder, blocks, polished stud...) as well as potentially on the field ${ }^{16}$.

The objective of this paper is therefore to study the feasibility of using reflectance spectroradiometry to distinguish a selection of ferruginous rocks presenting a variety of textures, initially under controlled laboratory conditions. Thanks to a series of measurements made at the spectro-gonio radiometer facility at IPAG (Institute of Planetology and Astrophysics of Grenoble, UGA/CNRS), we investigate the possibility of establishing a correlation between the variations in reflectance and spectral signature of the different samples and the diversity of mineral phases associations. The first objective is to compare well-characterized ferruginous materials according to a robust methodology based on data acquisition on shared standards with several analytical tools, compatible with the constraints related to archaeological objects. The geological materials studied in this paper have been selected to be sufficiently representative of the diversity of ferruginous rocks in terms of petrography, mineralogy and chemistry, and also to serve as standards for intercomparison between analytical methods.

\section{MATERIALS AND METHODS}

\section{Geological samples selection}

Thanks to geological surveys based on satellite photography, mining and geological documentation (BRGM), the Pigmentothèque project aims to collect and document the vertical and lateral variability of coloring matter deposits. The recording includes photographic coverage and geological description of outcrops and the various lithologies present, their GPS referencing and their location on geological and topographic maps (Fig. 1). We present here the 6 rock samples 
selected for their clear-cut genetic and intrinsic characteristics to be used as standards in order to compare all the measurements made with different instruments on both geological and archaeological objects.

Roussillon, Valaurie and Pierrerue samples are examples of weathering products giving coloring matter: Roussillon (Vaucluse) is an ochre profile formed on top of Cenomanian glauconite-rich sand/sandstones, Valaurie (Drôme) is an equivalent to Roussillon and Pierrerue (Béziers, Hérault) ferricrete covers a Jurassic bauxitic weathering profile. The sample of Valaurie is not yet considered as a reference due to the lack of geochemical and mineralogical characterization. So, the petrographic and mineralogical results of this sample will therefore not be detailed here, but its use will be limited to the preparation of several layers of paint on limestone.

Bordezac (Gard) samples illustrate the case of a hydrothermal hematite-rich vein. Huy (Belgium) samples are examples of Oolitic Iron Stones (OIS) from the Famennian Formation of Hodimont.

Two ferruginised limestones rich in crinoid fragments have been also selected because of their specific formation. The one of Beauregard (Thoste, Côte d'Or) is a Hettanginian biogenic limestone. The one in Pierremorte (Courry, Gard) is a Callovian limestone.

\section{Preparation of samples}

In addition to the raw blocks, several types of material textures were prepared: polished blocks, sawn blocks, fresh fractures, sieved powders as well as paint coating on limestone blocks.

In order to prepare a polished cube block (Fig. 2), it is necessary to adapt the preparation method to the mechanical properties and porosity of the sample. In the case of a compact, dense and very low-porosity material, saw cutting followed by polishing may be sufficient. But, for most samples that are more or less compact and porous, impregnation in epoxy resin (Araldite AR2020) is an indispensable step, requiring the mould to be placed in a closed desiccator under primary vacuum ( 0.8 to $0.9 \mathrm{mbar}$ ) for 2 to 4 hours. Beforehand, a degassing step allows to obtain a uniformity of the resin-sample stub. Under vacuum, a multitude of small bubbles are formed which can disturb the machining, observation and analysis. Degassing consists of placing the beaker filled with the resin-acetone-catalyst solution in a desiccator, then closing and placing under vacuum ( $0.6 \mathrm{mbar}$ ). In a few minutes (5 to 10 minutes depending on the volume) the gas bubbles disappear. Finally, the machining step allows to obtain the shape of a parallelepipedic block with a cutting saw, then the lapping is carried out with a pre-polishing (Plan grinding, 320 600 - 1200, $300 \mathrm{rpm}$ ) before a very fine polishing (Fine Grinding, 3 - 1 - 1/4 micron, $150 \mathrm{rpm}$ ).

The powders are obtained by grinding pieces of material in an agate mortar followed by sieving, generally below $160 \mu \mathrm{m}$ (and in one case also the > $160 \mu \mathrm{m}$ fraction was also measured), but for two pigments we also studied the effect of grain size in four different size ranges $(<50 \mu \mathrm{m}, 100$ $200 \mu \mathrm{m}, 200-400 \mu \mathrm{m}$ and $>400 \mu \mathrm{m}$ ). A cylindrical aluminium sample holder is then filled with the powder and its surface is lightly packed and smoothed with the handle of a spatula. Several sizes, ranging from $D \times d=7 \times 2$ to $38 \times 6 \mathrm{~mm}\left(80-6800 \mathrm{~mm}^{3}\right)$, have been used depending on the instrument, on the amount of material available and its brightness. The density of the porous powder material can be accurately obtained from the measurement of its weight (typically between $100 \mathrm{mg}$ and $15 \mathrm{~g}$ ) and sample holder volume. For our samples they ranged between 0.75 and $1.65 \mathrm{~g} / \mathrm{cm}^{3}$. 
Painting is prepared by mixing some powder with a few drops of water (quantity adapted to the material) to obtain a homogeneous painting matter with a smoothness suitable for application by brush on a porous limestone substrate. One or more layers of painting matter can be applied depending on the covering power and desired paint thickness (Fig. 3).

\section{Petrographical observation}

Macroscopic to microscopic observations (bare eye, binoculars, petrographic microscope, scanning electron microscope) are necessary to characterise all types of coloring matter. These observation tools are used in complementarity in order to link the different observation scales and to guide the bulk analysis (sensu stricto) or analysis on selected or isolated spots. Geological references are described according to the criteria of description and determination of rocks (described by their structure, texture, granulometry, color, hardness, figured elements such as fossils, bioclasts, lithoclasts or minerals, the presence of cement or matrix, their porosity...) following published visual charts (abundance, granulometry, sphericity and roundness....). The names of the rocks follow the rules of the associated charts such as the Dunham (1962) ${ }^{17}$ or Folk $(1962)^{18}$ charts for sedimentary rocks. Thus most of the quantitative and qualitative inherent properties are described. And the coloring matter is defined by its nature, variability, genesis and evolution through time ${ }^{19}$.

\section{SEM and XRD acquisition}

The analytical method used to study the samples consists in observation with a Scanning Electron Microscope coupled with an Energy Dispersive X-ray detector (SEM-EDX), in order to visualize the micro-morphology and to identify the chemical composition. The SEM LEO STEREOSCAN 440 coupled with an X-ray analyser SDD Bruker (in high vacuum mode; $20 \mathrm{keV}$ beam voltage; images obtained in secondary electron or backscattering electron modes) was used (platform ASTRE, USMB).

The X-ray diffraction was performed on powder in reflection mode on sample holder (XRD: INEL; CoK $\alpha$ X-ray tube; $1.5 \times 0.1$ slit; generator INEL XRG3D $30 \mathrm{~mA}, 30 \mathrm{kV}$; sensitive detector of curve position INEL CPS120 at $0.08^{\circ} \mathrm{FWHM}$ resolution for real-time simultaneous data acquisition). The mineralogical species were identified using the Match $!^{\odot \square}$ software.

\section{Spectro-gonio radiometers: set-up and acquisition parameters}

The Cold Surface Spectroscopy facility of the IPAG laboratory (https://cold-spectro.sshade.eu/) holds two home-made spectro-gonio radiometers, SHINE ${ }^{20}$ and SHADOWS ${ }^{21}$ that allow records of reflectance spectra in the visible and infrared ranges (350 - $4800 \mathrm{~nm}$ ) over a wide range of illumination $\left(0-80^{\circ}\right)$ and observation angles (emergence: $0-80^{\circ}$, azimuth $0-180^{\circ}$ ) and with a high radiometric accuracy. They have been used to characterize the spectral reflectance of the selection of standard ferruginous rocks. 
A 'standard' illumination/observation geometry (incidence $0^{\circ}$, emergence $30^{\circ}$ ) has been used to measure the spectra mostly covering the spectral range between 400 and $4200 \mathrm{~nm}$, but sometimes extending to $360 \mathrm{~nm}$ and/or $4800 \mathrm{~nm}$ according to samples. The first exploratory measurement campaign in October 2019 was carried out with resolutions between 10 and $40 \mathrm{~nm}$, but it was decided to use a 2.5 times better spectral resolution $(4-15 \mathrm{~nm})$ and a spectral sampling between 4 and $8 \mathrm{~nm}$ for all subsequent measurement campaigns in order to resolve some narrow water and hydroxyl bands and to obtain an homogeneous data set compatible with the performances of the currently available portable instruments, with the prospect to compare them with future field measurements. Samples of the different types are placed under the monochromatic illumination beam and their reflected light spectrum is acquired (from 45 min to $3 \mathrm{~h}$ of measurement depending on the Signal-to-Noise ratio, the spectral range and resolution chosen). The illumination spots are $5.2 \mathrm{~mm}$ (SHADOWS) and $7.5 \mathrm{~mm}$ (SHINE) in diameter. The measurements are calibrated in 'reflectance factor' using 2 reference targets (Spectralon ${ }^{\circledast}$ and Infragold ${ }^{\circledR}$ ) characterized and calibrated in absolute photometry at IPAG and measured a few times during each campaign. Thanks to these calibrations and a dynamically stabilized light source the absolute radiometric accuracy is better than $0.5 \% 20,21$. Post processing of the calibrated spectra is made in order to correct any spectral signature of atmospheric water, due to possible temporal variations of its partial pressure in the optical path between sample and last Infragold ${ }^{\circledR}$ reference measurements. The residual water vapor lines, around 1120, 1380, 1870 and 2665 nm, have been corrected by dividing the spectrum by a scaled normalized water vapor transmission spectrum measured with the instrument at same resolution and sampling. The scaling factor $f$ is adjusted to cancel the narrow spectral lines of water vapor (Fig. 4). Weak residual fluctuations $(<0.5 \%$ reflectance for the strongest bands in the $2550-2800 \mathrm{~nm}$ range) may remain when the water vapor variation is large and when a change in room temperature also occurred between the sample and the reference water spectrum measurements.

\section{RESULTS AND DISCUSSION}

1. Petrological and mineral description of the samples

The petrographic observation with bare eye and binocular enables to identify the six reference samples (Fig. 2):

- Huy (Belgium, Fig. 2A) is identified as Clinton-type Oolithic Iron Stone (OIS) with well sorted ferruginous flax seeds ooids with bioclastic, quartz $(100 \mu \mathrm{m})$ or rare lithoclastic nuclei. The ooids are embedded in dolomite and ferruginous clayey matrix and cement.

- Pierrerue (Béziers, Hérault, Fig. 2B) are irregular ferruginous pisoliths coming from an iron duricrust in a bauxitic profile and containing mainly hematite.

- Pierremorte (Courry, Gard, Fig. 2C) is a ferruginised limestone containing partly ferruginised crinoid fragments in a ferruginised carbonated matrix. 
- Roussillon (Vaucluse, Fig. 2D) is a ferricrete fragment from the top of the ochre profile. The iron duricrust is composed of corroded quartz grains $(200-400 \mu \mathrm{m})$ in a kaolinitic and ferruginous matrix.

- Beauregard (Thostes, Côte d'Or, Fig. 2E) is a limestone composed mainly of entirely ferruginised crinoid fragments $(3 \mathrm{~mm})$ in a ferruginised carbonated cement.

- Bordezac (Gard, Fig. 2F) is an hydrothermal metallic vein composed of hematite and rare tabular micas $(100 \mu \mathrm{m})$ and quartz inherited from the Triasic bedrock.

The observations at several scales combined with the chemistry and the X-ray diffraction of each sample lead to the description summarized in Table 1 and illustrated in figure 5. It is to be noted that hematite when well crystallised in large platelets tends to acquire a purple color ${ }^{26}$, however, its powder stays red.

\section{Reflectance spectra of red coloring matter}

The Visible-infrared spectra $(400-4200 \mathrm{~nm}$ ) of the six reference samples as sieved powders (grain size $<160 \mu \mathrm{m}$ ) are presented in Figure 6 and the spectra for the different preparations (powders, blocks and polished plots) are grouped per pigment in the series of Figures 8a-f. A number of features can be recognized in these spectra, characteristic of the oxidation state of iron, the presence of $\mathrm{OH}$ groups, water in various states (in the structure, adsorbed, bulk, ...), and carbonate ions.

In the visible range $(<1000 \mathrm{~nm})$ there are 4 wide absorption bands due to different electronic transitions of iron, the first, around $430 \mathrm{~nm}$, being a ligand field transition of $\mathrm{Fe}^{3+}$ ( $\mathrm{Fe}-\mathrm{O}$ bond) in hematite ${ }^{22}$. This band is extremely strong and fully saturated in all pigments and has on its high wavelength side a very strong band around $540 \mathrm{~nm}$ assigned to the double exciton process of a Fe-Fe pair. This last band also exists in goethite but is much weaker. These 2 bands cannot be distinguished in reflectance spectra as they absorb almost all light within the very first grain (reflectance 3-5\% below $550 \mathrm{~nm}$ ) for all materials containing a significant amount of hematite, as for our 6 standard pigments. The third weaker band around $640 \mathrm{~nm}$ appears as a shoulder and is due to another ligand field transition of $\mathrm{Fe}^{3+}$. This shoulder is more marked in goethite than in hematite. The last band, also due to a ligand field transition of $\mathrm{Fe}^{3+}$, is slightly variable in position and is situated between $860 \mathrm{~nm}$ (Huy) and $870 \mathrm{~nm}$ (Roussillon), but displays only little difference in relative band depth between most of these materials. This band is wider and shifted to $920 \mathrm{~nm}$ in pigments dominated by goethite (Fig. 7, and 8e).

The general shape between 1050 and $2600 \mathrm{~nm}$ is more variable and the origins of its variations are poorly documented. Roussillon is the brightest sample in this range with a maximum reflectance around $1850 \mathrm{~nm}$ close to 0.8, a strong 'red' slope (increasing reflectance with wavelength) below $1600 \mathrm{~nm}$, but a marked 'blue' slope (decreasing reflectance with wavelength) above 2050 nm, while Pierremorte, Bordezac and Huy have a very similar nearly flat, but slightly concave, reflectance with medium level (0.3-0.4, slight blue slope below $1500 \mathrm{~nm}$ and slight red slope above $1900 \mathrm{~nm}$ ). On the other hand, Beauregard displays a clear 'red' slope over almost the whole range, while Pierrerue has a 'blue slope' at both ends of this range (1050-1400 nm and 
2200-2600 nm). The blue slope above $1900 \mathrm{~nm}$ is clearly due to kaolinite which is indeed a major constituent of Roussillon and Pierrerue, but the marked blue slope at shorter infrared wavelength of the latter pigment (see also Fig. 8f) is still unexplained but possibly due to the alumina minerals only present in this pigment (Table 1). The extended red slope of Beauregard over the whole nearIR is also unexplained yet given its known composition. Over this 'continuum infrared absorption' there are mostly three groups of bands around $1400 \mathrm{~nm}$ (hydroxyl OH stretching mode and $\mathrm{H}_{2} \mathrm{O}$ combination modes), $1930 \mathrm{~nm}$ ( $\mathrm{H}_{2} \mathrm{O}$ stretch + bend combination) and $2200 \mathrm{~nm}$ (OH stretch + bend combination). The 1400 and $2200 \mathrm{~nm}$ features frequently have a double peak around 1395 and $1415 \mathrm{~nm}$, and 2165 and $2210 \mathrm{~nm}$, respectively (the second being stronger and narrower), typical of the first overtone of the hydroxyl $\mathrm{OH}$ stretching mode and of the combination between stretching and bending modes of kaolinite $\left[\mathrm{Al}_{2}\left(\mathrm{Si}_{2} \mathrm{O}_{5}\right)(\mathrm{OH})_{4}\right]$ (Fig. 7). They are present only in Pierrerue and Roussillon, and quite strong in the latter. The $1930 \mathrm{~nm} \mathrm{H} \mathrm{H}_{2} \mathrm{O}$ band is wide and is clearly seen only in Roussillon, partly due to its higher reflectance, but is very weakly present (band depth $<0.004$ ) in all others, more opaque, materials.

In addition, $\mathrm{OH}$ and $\mathrm{H}_{2} \mathrm{O}$ also express with their very strong fundamental vibrations $(\mathrm{OH}$ stretching and symmetric and antisymmetric stretching vibrations of $\mathrm{H}_{2} \mathrm{O}$ ) in the $2650-2800 \mathrm{~nm}$ range. Each of these vibration modes can also have several components depending either on the orientation of different types of $\mathrm{OH}$ in the crystal structure or on the cation ( $\mathrm{Si}, \mathrm{Fe}, \mathrm{Al}, \mathrm{Mg}$...) with which they interact. Both Pierrerue and Roussillon have 4 narrow components at 2704, 2721, 2734 and $2760 \mathrm{~nm}$ typical of the vibrations frequencies of the inner hydroxyl and the three inner-surface hydroxyls of kaolinite ${ }^{23}$. On the other hand all other materials have only a wide $\mathrm{OH}$ band between $2758 \mathrm{~nm}$ (Bordezac) and $2770 \mathrm{~nm}$ (Pierremorte) with a weak shoulder around $2700 \mathrm{~nm}$. The most marked and blue shifted $\mathrm{OH}$ band in Bordezac is due to micas (see muscovite spectrum in Fig. 7), a major component of this pigment. The associated narrow bands at 1410 and $2220 \mathrm{~nm}$ (Fig. 7) are weakly seen in the powder but clearly visible in one block (\#3) of Bordezac (Fig. 8b), thus confirming this identification. On the other hand, quartz is probably a major contributor of the $2770 \mathrm{~nm}$ band of Pierremorte and Huy. Beauregard displays only a weak band as a shoulder of the wide and strong band covering the whole $2800-4000 \mathrm{~nm}$ range. This latter band is partly due to $\mathrm{H}_{2} \mathrm{O}$ in the crystal structure (around 3100-3200 nm), and to adsorbed $\mathrm{H}_{2} \mathrm{O}$ (around 2850-2950 nm) (see e.g. ${ }^{24}$ ) but hematite $\left[\alpha-\mathrm{Fe}_{2} \mathrm{O}_{3}\right]$ (or hydrohematite, with part of the $\mathrm{O}$ replaced by $\mathrm{OH},[\sim \alpha-$ $\left.\left.\mathrm{Fe}_{1.83}(\mathrm{OH})_{0.5} \mathrm{O}_{2.5}\right]\right)$ and goethite $\left[\alpha-\mathrm{Fe}^{3+} \mathrm{O}(\mathrm{OH})\right]$ also strongly contribute around 2930 and $3150 \mathrm{~nm}$, the second band being almost as strong as the first one for goethite, but only present as an extended wing in hematite ${ }^{25}$ (Fig. 7). The band around $2930 \mathrm{~nm}$ is relatively similar in almost all our standard pigments except Pierrerue which seems to have a stronger band and shifted toward lower wavelength $(2890 \mathrm{~nm}$ ). The $3150 \mathrm{~nm}$ band is particularly strong for Roussillon and strong for Beauregard where goethite was identified, but also more weakly seen in Huy and Pierremorte spectra (Fig. 8c,d) despite goethite has not been identified in the latter pigment. On the contrary, there is no spectral sign of it in Pierrerue where goethite is one of the identified minor constituting minerals (Table 1).

Finally Pierremorte and Huy display a series of strong bands above 3300 nm (3355, 3482, 3980 $\mathrm{nm}$ with shoulders at $\sim 3860 \mathrm{~nm}, 4660 \mathrm{~nm}$ ) characteristics of calcite (overtone and combination of 
the $\mathrm{C}-\mathrm{O}$ stretching and bending vibrations of the $\mathrm{CO}_{3}{ }^{2-}$ ion). Dolomite has also a very similar band pattern but globally slightly shifted to lower wavelengths (Fig. 7). It has also a distinct band at 3810 $\mathrm{nm}$ plus some weaker bands at 4285 and $4450 \mathrm{~nm}$ (out of our nominal spectral range) allowing to distinguish between these two carbonates. A few weak combination bands of this ion are also barely seen in the powders at $\sim 2340,2534 \mathrm{~nm}$ (with shoulder at $\sim 2490 \mathrm{~nm}$ ) but very clearly seen in all blocks and polished plot spectra of Pierremorte (Fig. 8b). It should be noted that the calcite bands seen in the spectra of Pierremorte and Huy look very similar despite very different types of rocks and geologic histories. Finally pure quartz did not display strong and uniquely identifiable bands in the near-infrared. However, it generally contains some water molecules and hydroxyls in its structure which give rise to bands around 1900-1940 nm and 2210-2250 nm, respectively. These bands are clearly seen (at 1905 and $\sim 2240 \mathrm{~nm}$ ) in our reference spectrum of natural quartz (Fig. 7). The wide and moderately strong band peaking in the 1915-1940 $\mathrm{nm}$ range (depending on sample) in Roussillon spectra (Fig 6 and 8e) is most probably the signature of structurally bond water in quartz, a major constituent of this pigment (Table 1). But this band is present as a weak to very weak absorption in all pigments with or without quartz identified by XRD, as it is not very specific to the mineral in which water is trapped. Laboratory spectra of quartz also display a group of moderately strong bands between 2845 and $3015 \mathrm{~nm}$ due to $\mathrm{OH}$ - ions to equilibrate cations impurities and to isolated structural bond water molecules trapped in the quartz, but the very strong hematite/goethite bands strongly interfere with these bands within that range. The only band in the range of the solar spectrum, but lying above $4200 \mathrm{~nm}$, that can be used to identify quartz is the first overtone of its $\mathrm{Si}-\mathrm{O}$ stretching mode at $4470 \mathrm{~nm}$ and marginally its much stronger combination with bending modes just above $5000 \mathrm{~nm}$. Baryte, which is present in half our pigments, has no specific band below $4200 \mathrm{~nm}$, except the generic absorptions around 1450 and $1930 \mathrm{~nm}$ of possible small amounts of water of hydration of this sulfate, but it displays a series of very strong bands in the $4250-4900 \mathrm{~nm}$ range due to the different overtone and combination bands of the stretching modes of the $\mathrm{SO}_{4}{ }^{2-}$ sulfate ion (Fig. 7). We measured only a few samples up to $4800 \mathrm{~nm}$, due to the time necessary to achieve a good Signal-to-Noise, but on one block of Beauregard we possibly observed (low S/N data) a series of bands between 4400 and $4700 \mathrm{~nm}$ which may be due to a sulfate. The other minor constituents identified by XRD, chlorite, siderite, calcium phosphate, xenotime and zircon (Table 1), some of which have several characteristic bands in the visible and near-infrared, are not detected due to their generally low abundances or to interference of their bands with those of major constituents (e.g. the two narrow bands of Zircon at 2708 and $2762 \mathrm{~nm}$ fall within the strongest of the four narrow bands of kaolinite, at 2704 and $2760 \mathrm{~nm}$ ). Finally it should be noticed that in several spectra of blocks (see e.g. Bordezac in Fig 8b), there are two bands at 3415 and $3500 \mathrm{~nm}$ not linked with the minerals but attributable to the $\mathrm{C}-\mathrm{H}$ fundamental stretching vibrations of $\mathrm{CH}_{2}$ and $\mathrm{CH}_{3}$ groups in organic material, probably slightly contaminating the surface of these blocks. These bands are never seen in powders.

The band analysis of the reflectance spectra obtained for each reference sample complements well the chemistry and X-ray diffraction analyses and characterizations described in the previous section. Indeed, reflectance spectroscopy is sensitive to the nature of the chromogenic mineral, here hematite or goethite, but also to the other major constituents. On the other hand, it is difficult to access relative abundance in the case of mixture. It is also relevant to identify the rock 
matrix, particularly in the case of limestone rocks (carbonate bands, calcite or dolomite), although it is less obvious for the presence of quartz. Although the minerals that can be associated with iron oxides in these rocks have characteristic bands, their detection by reflectance spectroscopy, except for kaolinite, is delicate due to their low abundance and the detection limit of the method. On the other hand, the presence of the characteristic bands of hydroxyl ion and structural water and the sensitivity of the position of these bands as a function of the associated cation are very interesting and particularly complementary to the macro and microscopic observation methods and the analysis of minerals (EDX and DRX) which are not relevant in this case.

\section{The effect of the preparation}

\subsection{Effect of granulometry}

In the case of Roussillon material, we measured two grain size ranges, below and above $160 \mu \mathrm{m}$ with two different densities. The difference is mostly a decrease of about $12 \%$ of the overall reflectance when going from fine to larger grains, without any noticeable change in the occurrence or relative intensity of the various absorption bands and slopes (Fig. 8e).

We also measured the reflectance spectra of Roussillon and Huy powders with 4 different grain size ranges: $<50 \mu \mathrm{m}, 100-200 \mu \mathrm{m}, 200-400 \mu \mathrm{m},>400 \mu \mathrm{m}$ (Fig. 9a,b). For the first 3 size ranges, as expected, the reflectance decreases with grain size regularly over the whole spectral range, except in the strongest electronic bands, in the visible below $550 \mathrm{~nm}$, where the light is already absorbed in the very first grain it encounters. However, the spectrum for the largest grains did not follow the trend, in particular for Roussillon in the visible and very near infrared dominated by hematite and goethite absorptions (Fig. 9a). A possible explanation is that there is some difference in abundance or distribution of the materials composing the Roussillon sample in this size range compared to the smaller sizes. Indeed, for the larger grain size the abundance of the very finely grained phase made of clayey ferruginous matrix containing kaolinite, hematite and goethite should be decreased during sieving relative to the quartz phase as the latter is mostly present as large grains, with average size above $300 \mu \mathrm{m}$ (Fig. 5-9 and 5-10). The slight increase of reflectance in the $2800-4000 \mathrm{~nm}$ range, also dominated by goethite and hematite absorptions, seems to confirm this hypothesis.

For Huy (Fig. 9b) we have a similar effect but with a stronger reduction of reflectance of the 100$200 \mu \mathrm{m}$ size range relative to the $<50 \mu \mathrm{m}$ fraction, and an opposite effect for the largest one (> $400 \mu \mathrm{m})$ : the absorption outside the hematite absorption range $(1000-2700 \mathrm{~nm})$ is increased, so possibly due to a change in relative abundance of the material contributing to this spectral range.

\subsection{Raw block versus powder}

When comparing the spectrum of a powder with that of the raw blocks of the original material (Fig. 8a-f, and 10) one generally observes an overall decrease in reflectance (except in the $500 \mathrm{~nm}$ band which saturates at the 0.06-0.13 reflectance level for blocks instead of 0.03-0.055 for powders) with similar continuum slopes and absorption bands, sometimes with similar band intensities such as for block \#1 of Beauregard, Pierremorte and Pierrerue (Fig. 8a,d,f), or with increased intensities of some bands, such as for the iron bands in the visible and the carbonate bands in the near and mid-infrared (above $1900 \mathrm{~nm}$ ) of block \#2 and \#3 of Pierremorte (Fig. 8d 
and 10), along with sometimes a change of the infrared continuum slope (more 'red' for block \#2). In Figure 10 we compare the powders $(<160 \mu \mathrm{m}$ grain size) with the most different block of the same material. There are clear changes in slopes and band intensities but the occurrence of these characteristic bands remain unchanged.

It appears that in some cases the composition probed by the measurement spot at the surface of a raw block is relatively different from the global 'bulk' composition probed in the well mixed grains of a powder. It should be noted that the depth of light penetration is typically of the order of the millimetre at 'bright wavelengths (reflectance $>0.7$ ) but only a few microns to tens of microns in some extremely strong electronic absorption bands, such as below $600 \mathrm{~nm}$.

For example, on Huy (Fig. 8c) the component(s) at the origin of the slightly concave continuum absorption in the infrared spectra of powders seems to dominate in the measurement spot of the raw blocks, and even more on a freshly sawn face, to the detriment of the intensity of both the iron bands and carbonate bands. However, although the shape of the spectrum seems quite different (e.g. with a strong 'blue' slope between 1000 and $2500 \mathrm{~nm}$ ), all the characteristic bands are still present, but moderately to strongly attenuated.

The case of Bordezac ( 2 blocks measured on 2 faces each) is also interesting as the main changes are now mostly in the water bands (Fig. 8b). The spectra of the powder and that of face \#3 of block $\# 2$ have very similar spectra up to $2800 \mathrm{~nm}$ (except absolute intensity) but above that wavelength the absorption is stronger and wider and peaking at a somewhat larger wavelength. This is typical of an increased contribution of structural $\mathrm{H}_{2} \mathrm{O}$. On face \#1 of this same block \#2, this water band is even stronger with a larger spectral shift ( $3000 \mathrm{~nm}$ instead of $2940 \mathrm{~nm}$ for the powder). It also displays weak 1420 and $1920 \mathrm{~nm} \mathrm{H} \mathrm{H}_{2} \mathrm{O}$ bands (micas) and a slight 'blue' slope above $2300 \mathrm{~nm}$. Both measured faces of block \#3 have also strong structural water absorption but display a flattening of the 'red' slope, seen above $1600 \mathrm{~nm}$ in the spectrum of the powder, and an increased 'blue' slope below $1850 \mathrm{~nm}$ (as in the block of Huy). Its raw face \#2 also displays stronger characteristic bands of muscovite (mica), barely seen on face \#1 of block \#2.

Bloc \#3 of Roussillon displays a particular change relative to the powder with a higher continuum level before the $1930 \mathrm{~nm}$ band, but a very similar spectrum at higher wavelength (Fig. $8 \mathrm{e})$. The yet unidentified component widely absorbing between about 1100 and $1850 \mathrm{~nm}$ should thus be present at much lower abundance. In addition its visible absorption bands are shifted ($20 \mathrm{~nm}$ for the $\sim 450 \mathrm{~nm}$ band, $+50 \mathrm{~nm}$ for the $915 \mathrm{~nm}$ ) with modified width and intensity which is characteristic of an increased proportion of goethite relative to hematite probed at the surface of this block compared to the mean mineralogy of the powder. The fresh face of block \#4 display a similar but less marked composition difference. On the other hand, block \#1 displays a $860 \mathrm{~nm}$ hematite band identical to the powder and a weaker increase of the continuum below $1850 \mathrm{~nm}$ (Fig. 8e). It should thus have a composition more similar to that of the powder.

A last clear difference between the iron oxide composition of two blocks of the same material is the case of Beauregard (Fig. 8a) for which blocks \#1 and \#2 have exactly the same spectra between 1100 and $2770 \mathrm{~nm}$ as well as above $390 \mathrm{~nm}$ but clearly diverge in the other spectral ranges dominated by iron oxides. The changes appear to be both an increased proportion of goethite and a decreased total amount of iron oxides in block \#2, as witnessed by the change of band shape (stronger $615 \mathrm{~nm}$ shoulder, wider $880 \mathrm{~nm}$ band), position (+20 nm) and intensity in the visible range, correlated with those in the infrared. 


\subsection{Plots}

Spectral measurements have been also performed on a polished plot of each reference sample (Fig. 11). Compared to the corresponding powders it is relatively easy to recognise each pigment with the general shape of the reflectance curve and their particular spectral features. However the spectra of the plots have generally lower global reflectance, due to their less scattering surface, and the strongest bands are more saturated, in particular in the visible below 600-700 nm and in the mid-infrared above $2700 \mathrm{~nm}$, making it more difficult to recognize some constituents in this range. But in some cases additional bands clearly show up in the near-infrared, such as the relatively strong bands at 1680, 2160 and $2470 \mathrm{~nm}$ in Roussillon, or the series of weak bands at $1670 \mathrm{~nm}$ and between 2140 and $2460 \mathrm{~nm}$ in the otherwise smooth spectrum of Beauregard. In other cases these bands are just faintly discernible in the powder but get much stronger in the plot. They point to mineral constituents not listed in the nominal composition of Table 1, but yet to be identified.

\subsection{Paints on substrates}

\subsubsection{Different paints on limestone}

A blind test has been made on 8 painting matters deposited in a thin layer (but opaque in the visible) on a limestone substrate (Fig. 3) in order to assess if visible-infrared reflectance spectroscopy alone is able to identify the matters used by simply comparing their spectra with a wide set of powder and block spectra. Spectra were recorded where the painting layer appeared to be the thickest (Fig. 12). A reference spectrum of the bare limestone has been also measured. We first restricted the comparison of these spectra to the $400-2500 \mathrm{~nm}$ range available in most portable field spectrometers. The result is that most painting matters were recognized with just a couple attributed to matters having very similar spectral signatures below $2500 \mathrm{~nm}$, but that can be disambiguated at higher wavelength (2500-4200 nm). In particular, it is difficult to attribute paint $B$ to either Bordezac, Huy or Pierremorte because the two last differ from the Bordezac only by the presence of the carbonate bands (Fig. 6), which can be easily confused with the much stronger bands of the limestone substrate, especially below $2500 \mathrm{~nm}$ where they are very weak in the powders. In fact the thickness and reflectance level (linked to the mean penetration depth of the light) of the painting matter appear to mostly control the visibility of the substrate spectral signatures. In the visible range where the painting layers have very strong absorptions their spectral signatures are almost unchanged relative to the powders. They are completely opaque. There is a similar behaviour in the near-infrared when the reflectance is typically below 0.3 (see e.g. the very weak bands of the limestone in painting $C$, Beauregard) while when it is around 0.6 the carbonate bands of the substrate are clearly seen through the painting matter (see e.g. the strong bands of the limestone in paint B, Pierremorte). For Roussillon the paint layer is thick enough to display the series of narrow absorption bands of the powder and almost fully hide the carbonate bands of the substrate..

\subsubsection{Effects of painting layer thickness and substrate type}


We then tested the effect of paint thickness for different pigments (Huy, Valaurie) on substrates with different composition and brightness (various limestones, serpentine). We show in Fig. 13a the case of the Huy paint deposited in 3 successive thin layers over a flat bare calcite slice, compared to the spectra of both the bare calcite and the Huy powder $(<160 \mu \mathrm{m})$ used to prepare the paint. Right from the first thin layer the absorption bands of hematite in the visible are very strong and almost fully hide the bright calcite, thanks to the very strong absorption coefficients of these bands. The paint becomes opaque in the visible range with probably only a few tens to hundred micron thick layer. In the near infrared, up to $2700 \mathrm{~nm}$, the Huy pigment only displays a flat and moderately transparent spectrum (reflectance $0.3-0.35$ ) so its only effect is to progressively attenuate the intensity of the calcite bands and decrease the reflectance. The thickness needed to fully hide calcite in the near infrared is then more in the range of several hundred microns to millimeter. However as this pigment also contains some calcite, the strongest bands above $3300 \mathrm{~nm}$, fully saturated in the bulk substrate, progressively reappear as the thickness of the painting layer increases.

When the paint displays also some specific absorptions, as in Valaurie (Fig. 13b), they progressively appear and grow in intensity as the painting layer thickness increases, up to the point the paint is thick enough to be opaque at wavelengths, as for layer 4 . With a bright paint such as Valaurie (similar to Roussillon) the reflectance of the layer increases with its thickness contrary to a darker paint, as Huy, for which its overall brightness over a bright substrate decreases with thickness. In both cases their spectrum tends towards the reflectance of the original powder.

\subsubsection{Effect of the observation-illumination angles}

In order to assess the possibility to preferentially probe thin layers of paint and reduce the contribution of the spectral signatures of the substrate, we recorded a series of spectra with varying incidence and emergence angles $\left(i=0,60,70^{\circ}, e=30,60,70^{\circ}\right)$ on two different paints (Huy and Valaurie, an ochre of Roussillon type) with a thickness thin enough to still display strong calcite bands (Fig. 14). In the case of the relatively bright ochre pigment (reflectance $>0.6$, so quite transparent in the infrared) there is a very clear decrease of the intensity of the calcite bands, by almost an order of magnitude, when going from the standard near-nadir observation $\left(i=0^{\circ}\right.$, e $\left.=30^{\circ}\right)$ to more grazing illuminations $\left(i=60,70^{\circ}\right)$. However when the illumination and observation angles are too high the depth of the spectral signatures of the paints are also strongly reduced, except for the strongest bands in the visible and very near-infrared $(<1000 \mathrm{~nm})$. Indeed, at high incidence angles the light, on one side, penetrates to a shallower depth, so is less absorbed by the substrate, but on the other side it escapes from the paint layer after less scattering events, so also reducing the pathlength traveled in the layer. A good combination to differentiate the absorptions by the pigment and the substrate seems to perform at least one 'near-normal' measurement $\left(i=0^{\circ}\right.$, $\mathrm{e}^{\sim} 30^{\circ}$ ) to get the strongest pigment absorption bands and one with a high incidence angle to be able to see how the relative intensities of the bands from the paints and the substrate vary. For this last one the best compromise seems to be around the geometry $\mathrm{i}=\mathrm{e}=60^{\circ}$.

For Huy (not shown) which has a lower global reflectance, so less transparent in the near-infrared, increasing the illumination angle is more efficient to attenuate the carbonate bands, and creates a 'red slope' in the near-infrared. But the absence of spectral signature of Huy in that range did not provide additional information on composition. 


\section{CONCLUSION}

The prospecting carried out to date to collect ferruginous rocks with coloring properties has led us to gather a collection of more than two hundred outcrops of ferruginous rock that present a wide range of mineralogically, chemically and petrographically different materials. However, their simple color is not sufficient to discriminate them and the use of radiometrically accurate visible and near-infrared diffuse reflectance spectra can therefore be useful to allow the categorization of these different materials. We have shown on a first set of geological reference samples that the recording of reflectance spectra in the $400-4200 \mathrm{~nm}$ range should allow to provide the exact color in the visible range, to identify various iron oxides (hematite, goethite, maghemite ...) and additional minerals (kaolinite, carbonates, sulphates, micas, ...), and to get information on the presence of structural $\mathrm{H}_{2} \mathrm{O}$ and $\mathrm{OH}$ and the cations with which they interact. The comparison with a set of reference spectra of the constituting minerals (Fig. 7) should allow us to identify some of the minor constituents globally or locally present in the pigment materials. The direct comparison between raw blocks, sawn blocks, polished plots and powders is possible as mostly little changes in spectral signatures (bands and slopes) are observed, and only on band intensities and continuum level. But some variability in composition between blocks, or an heterogeneous distribution at small scale in a same block (local concentration of minor minerals, ...) may induce some changes in spectral signatures that may be exploited to identify some of the minor minerals by using a smaller observation spot (the same for polished plots). The effects of grain size of powders is also only on global reflectance level and on the intensity and saturation of absorption bands, thus preserving the key spectral signatures that characterize the material, even if some mineral sorting may slightly modify their relative intensities.

These first results open up the potential to compare spectra of painted matters with reference powders (or block) spectra to identify these paints. However, the spectral signature of the substrate must be known as it strongly interferes at all wavelengths where the paint is mostly transparent (high reflectance).

So spectroscopic field measurements appear to be interesting to easily get first information on painting matter without contact. This will need to take into account the substrate, but we have shown that measuring a paint at different places with different thicknesses (including the bare substrate) and also at a couple of very different illumination angles may provide a tool to help separate both contributions. This radiometric method may also provide some quantitative mineralogical information not provided by other techniques, such as structural water, $\mathrm{OH}$.... ${ }^{24}$.

It emerges from this first study that using the position/width/intensity of all the bands, as well as the continuum slope and reflectance level in different wavelength ranges, it should be possible to classify all the spectra of the coloring matters within a defined set of classes sharing similar spectral properties. It is thus planned to pursue in a systematic way the acquisition of the Vis-NIR spectra $(400-4200 \mathrm{~nm})$ of all the materials of the pigment library, to derive a number of parameters from their spectral signatures, and to perform their statistical analysis in order to determine the most representative spectral classification of the whole set of pigments. 


\section{ACKNOWLEDGEMENTS}

This program takes advantage of the financial and scientific support of the Regional Archaeological Service of the Auvergne-Rhône-Alpes region. We would like to thank K. Gernigon, Regional Curator of Archaeology, for his scientific support. Our thanks also go to L. Devillard for the administrative management and to the AVDPA for the management of the credits. We would like to thank the University of Savoie-Mont-Blanc for its financial support (MASCARA and TRAnSFeRT projects) and the ASTRE platform for access to measuring instruments (XRD, SEM-EDX). The SSHADE database infrastructure and the SHADOWS instrument have been developed in the frame of the Europlanet $2020 \mathrm{RI}$ programme which received funding from the European Union's Horizon 2020 research and innovation programme under grant agreements No 654208. We warmly thank all colleagues involved in the PCR Pigmentothèque and more particularly: J. Monney, J.-V. Pradeau, E. Goemaere (Service géologique de Belgique, Institut royal des Sciences naturelles de Belgique, Bruxelles, Belgique) and M. Henry (GET - Observatoire Midi-Pyrénées, Université Toulouse III).

\section{REFERENCES}


1. Pradeau, J.-V., H. Salomon, F. Bon, R. Mensan, M. Lejay, and M. Regert. 2014. Les matières colorantes sur le site aurignacien de plein air de Régismont-le-Haut (Poilhes, Hérault): Acquisition, transformations et utilisations. Bulletin de la Société préhistorique française 111 (4): 631-58.

2. Rifkin, R. F., L. Dayet, A. Queffelec, B. Summers, M. Lategan, and F. d'Errico. 2015. Evaluating the Photoprotective Effects of Ochre on Human Skin by In Vivo SPF Assessment: Implications for Human Evolution, Adaptation and Dispersal. Plos One 10 (9): e0136090. https://doi.org/10.1371/journal.pone.0136090.

3. Rosso, D. E., F. d'Errico, and J. Zilhão. 2014. Stratigraphic and Spatial Distribution of Ochre and Ochre Processing Tools at Porc-Epic Cave, Dire Dawa, Ethiopia. Quaternary International, Changing Environments and Movements through Transitions: Paleoanthropological and Prehistorical Research in Ethiopia. A Tribute to Prof. Mohammed Umer, $343 \quad$ (septembre): https://doi.org/10.1016/i.quaint.2013.10.019.

4. Beck, L., H. Salomon, S. Lahlil, M. Lebon, G. P. Odin, Y. Coquinot, and L. Pichon. 2012. Non-destructive provenance differentiation of prehistoric pigments by external PIXE. Nuclear Instruments and Methods in Physics Research B 273: 173-177. https://doi.org/10.1016/j.nimb.2011.07.068.

5. Popelka-Filcoff, R.S, E.J. Miksa, J. D. Robertson, M. D. Glascock, and H. Wallace. 2008. Elemental analysis and characterization of ochre sources from southern Arizona. Journal of Archaeological Science 35 (3): 752-762.

6. Zipkin, A. M., S. H. Ambrose, J. M. Hanchar, P. M. Piccoli, A. S. Brooks, and E. Y. Anthony. 2017. Elemental fingerprinting of Kenya Rift Valley ochre deposits for provenance studies of rock art and archaeological pigments. Quaternary International 430: 42-59.

7. Fernandes, P. 2006. Pétroarchéologie des matériaux siliceux utilisés au paléolithique moyen dans le sud du Massif central : méthodologie et résultats préliminaires. Mémoire de diplôme de l'Écoles des hautes études en sciences sociales, Écoles des hautes Études en sciences sociales, Toulouse, $183 \mathrm{p}$.

8. Fernandes, P. et J.-P. Raynal. 2006. Pétroarchéologie du silex : un retour aux sources, Comptes rendus Palevol $5: 6,829-837$.

9. Fernandes, P. et J.-P. Raynal. 2007. Pétroarchéologie du silex, in La grotte Sainte Anne 1. Le Paléolithique moyen de l'unité J1, Laussonne, Les dossiers de l'Archéo-Logis n³, Archéo-Logis/CDERAD (Éd.), p. 59-98.

10. Chassin de Kergommeaux, A., H. Salomon, J. Monney, C. Chanteraud, J.-V. Pradeau, E. Goemaere, T. Leduc, and E. Chalmin. 2021. Référencement géologique des ressources en matières colorantes entre l'Ardèche et le Gardon - un outil pour appréhender les paysages vécus au cours du Paléolithique supérieur, Ardèche Archéologie : 38.

11. Salomon, H., C. Chanteraud, A. Chassin de Kergommeaux, J. Monney, J.-V. Pradeau and E. Chalmin. accepted. A geological collection and methodology for tracing the provenance of Palaeolithic colouring matter. Journal of Lithic studies

12. Monney, Julien. 2012. Et si d'un paysage l'on contait passé. Tissu de sens et grottes ornées le long des gorges de l'Ardèche. Collection EDYTEM. Cahiers de géographie, 13: 21-42. https://doi.org/10.3406/edyte.2012.1203. 
13. Monney, J., J. J. Delannoy, B. Gély, J.-M. Geneste. 2020. Combe d'Arc, Pont d'Arc, Grotte Chauvet. In : Delannoy J.-J., Geneste J.-M. (dir.) - Atlas de la grotte Chauvet-Pont d'Arc : Volume 1 de la Monographie de la grotte Chauvet-Pont d’Arc, Éditions de la Maison des sciences de l'homme, Paris (Documents d'archéologie française).

14. Moncel, M.-H., and C. Daujeard. 2012. The variability of the Middle Palaeolithic on the right bank of the Middle Rhône Valley (southeast France): Technical traditions or functional choices?, Quaternary International 247 : 103-124.

15. Bishop, J. L. 2020. Visible and Near-Infrared Reflectance Spectroscopy Laboratory Spectra of Geologic Materials. in "REMOTE COMPOSITIONAL ANALYSIS - Techniques for Understanding Spectroscopy, Mineralogy, and Geochemistry of Planetary Surfaces" (Edited by Janice L. Bishop, James F. Bell, III, Jeffrey E. Moersch). Cambridge University press. pp. 68-101.

16. Konik, S. and D. Lafon-Pham. 2018. Apports de la colorimétrie et de la spectroradiométrie à la caractérisation in situ des peintures paléolithiques de la grotte Chauvet (Ardèche, France). Comptes rendus de physique 19:7, 612-624.

17. Dunham, R.J. 1962. Classification of carbonate rocks according to depositional texture. Bulletin of the American Association of Petroleum Geologists, 1: 108-121.

18. Folk, R.L. 1962. Spectral subdivision of limestone types. Bulletin of the American Association of Petroleum Geologists, 1: 62-84.

19. Salomon, H., E. Goemaere, C. Billard, R. Dreesen, D. Bosquet, C. Hamon, and I. Jadin. 2016. Analyse critique du protocole de caractérisation des hématites oolithiques mis en place dans le cadre du projet collectif de recherche sur L'origine des hématites oolithiques exploitées durant la Préhistoire récente entre l'Eifel (DE) et la Normandie (FR). Anthropologica et Praehistorica, Autour de l'hématite / About haematite. Circulation et transformation au cours de la Préhistoire récente / Procurement and transformation during Recent Prehistory. Actes de la Table-Ronde internationale / Acts of the international Round Table, 7-8/02/2013, Namur (Jambes), 125.

20. Brissaud, O., B. Schmitt, N. Bonnefoy, S. Douté, P. Rabou, W. Grundy, Band M. Fily. 2004. Spectrogonio radiometer for the study of the bidirectional reflectance and polarization functions of planetary surfaces: I. Design and tests. Appl. Optics, 43 (9), 1926-1937 [doi: 10.1364/AO.43.001926]

21. Potin, S., O. Brissaud, P. Beck, B. Schmitt, Y. Magnard, J.-J. Correia, P. Rabou, and L. Jocou. 2018. SHADOWS: spectro-gonio radiometer for bidirectional reflectance studies of dark meteorites and terrestrial analogs. Design, calibrations and performances on challenging surfaces. Applied Optics, 57 (28), 8279-8296 [doi: 10.1364/A0.57.008279]

22. Sherman, D. M., T. D. Waite. 1985. Electronic spectra of Fe3+ oxides and oxide hydroxides in the near IR to near UV. American Mineralogist 70: 1262-1269.

23. Farmer, V. C. 1998. Differing effects of particle size and shape in the infrared and Raman spectra of kaolinite. Clay Minerals 33: 601-604

24. Potin, S., S. Manigand, P. Beck, C. Wolters, B. Schmitt. 2020. A model of the 3- $\mu \mathrm{m}$ hydration band with Exponentially Modified Gaussian (EMG): application to hydrated chondrites and asteroids. Icarus, 343, 113686 [doi:10.1016/j.icarus.2020.113686, arXiv:2002.01296] 
25. Ruan, H.D., R.L. Frost, J.T. Kloprogge. 2001. The behavior of hydroxyl units of synthetic goethite and its dehydroxylated product hematite. Spectrochimica Acta Part A 57: 2575-2586.

26. Gerardin, M., N. Holzschuch, A. Ibanez, B. Schmitt, P. Martinetto. 2020. Correlation between micro-structural features and colour of nanocrystallized powders of hematite. Proceedings of the AIC Interim Meeting Natural Colours-Digital Colours, 26-28 November 2020, Avignon, France.

27. Schmitt, Bernard; Chalmin-Aljanabi, Emilie, Chassin de Kergommeaux, Aurélie. 2019a. Vis-NIR reflectance spectra of Beauregard pigments (PIG-0174-2016): raw blocks, powders, polished plot and painted matter. SSHADE/PIG (OSUG Data Center). Dataset/Spectral

Data.

https://doi.org/10.26302/SSHADE/EXPERIMENT BS 20200812100

28. Schmitt, Bernard, Chalmin-Aljanabi, Emilie, Chassin de Kergommeaux, Aurélie. 2019b. Vis-NIR reflectance spectra of Bordezac pigments (PIG-0160-2016-D): raw blocks, powders, polished plot and painted matter. SSHADE/PIG (OSUG Data Center). Dataset/Spectral

Data. https://doi.org/10.26302/SSHADE/EXPERIMENT BS 20200422100.

29. Schmitt, Bernard, Chalmin-Aljanabi, Emilie, Chassin de Kergommeaux, Aurélie. 2019c. Vis-NIR reflectance spectra of Huy pigments (PIG-0172-2016): raw block, powders with different grain sizes and densities, polished plot and painted matter. SSHADE/PIG (OSUG Data Center). Dataset/Spectral Data. doi:10.26302/SSHADE/EXPERIMENT BS 20200813100.

30. Schmitt, Bernard, Chalmin-Aljanabi, Emilie, Chassin de Kergommeaux, Aurélie. 2019d. Vis-NIR reflectance spectra of Pierremorte pigments (PIG-0020-2015): raw blocks, powders, polished plot and painted matter. SSHADE/PIG (OSUG Data Center). Dataset/Spectral Data. doi:10.26302/SSHADE/EXPERIMENT BS 20200815100.

31. Schmitt, Bernard, Chalmin-Aljanabi, Emilie, Chassin de Kergommeaux, Aurélie. 2019e. Vis-NIR reflectance spectra of Pierrerue pigments (PIG-0176-2016): raw blocks, powders, polished plot and painted matter. SSHADE/PIG (OSUG Data Center). Dataset/Spectral Data.doi:10.26302/SSHADE/EXPERIMENT BS 20200814100.

32. Schmitt, Bernard, Chalmin-Aljanabi, Emilie, Chassin de Kergommeaux, Aurélie. $2019 f$. Vis-NIR reflectance spectra of Roussillon pigments (PIG-0173-2016): raw blocks, powders with different grain sizes and densities, polished plot and painted matter. SSHADE/PIG (OSUG Data Center). Dataset/Spectral Data. https://doi.org/10.26302/SSHADE/EXPERIMENT BS 20191012400.

33. Hapke, B. 1993. Theory of reflectance and emittance spectroscopy. Topics in Remote Sensing, Cambridge, UK: Cambridge University Press.

34. Shkuratov, Y. and L. Starukhina. 1999. A Model of Spectral Albedo of Particulate Surfaces: Implications for Optical Properties of the Moon. Icarus, 137, 235-246.

35. Stamnes, K., SC. Tsay, W. Wiscombe and K. Jayaweera. 1988. Numerically stable algorithm for discrete-ordinate-method radiative transfer in multiple scattering and emitting layered media. Applied Optics, 27, 2502-2509. 
36. Douté, S., and B. Schmitt. 1998. A multi-layer bidirectional reflectance model for the analysis of planetary surface hyperspectral images at visible and near infrared wavelengths. Journal of Geophysical Research E, 103, 31367-31390.

\section{AUTHOR BIOS}

\section{Emilie Chalmin}

Lecturer at the University of Savoie-Mont Blanc, E. Chalmin conducts her research in the EDYTEM laboratory. She carries out this research around coloring materials found in archaeological contexts (in caves or rock shelters) in different periods of time (from the Upper Palaeolithic to the Neolithic) and in various geographical areas and geological contexts (Australia, Dordogne, Ardèche, Savoie). She is also interested in the processes of alteration of prehistoric paintings and the origin of natural coloring materials.

\section{Bernard Schmitt}

Research director at CNRS and Université Grenoble alpes, B. Schmitt conducts his research in the IPAG laboratory. He studies the composition and physical state of the surfaces of solar system objects using visible and near-infrared hyperspectral imagery onboard space exploration missions (ESA, NASA). He analyses these observations with laboratory data on natural or synthetic analogue materials measured with two home-made spectro-gonio radiometers and using radiative transfer models in granular and compact media. He was recently interested to apply these space-born techniques to the characterisation and identification of prehistoric pigments.

\section{Claire Chanteraud}

Young researcher in archaeological sciences (Dr), Claire Chanteraud realized her PhD in the EDYTEM laboratory at the University of Savoie Mont Blanc. She studies the prehistoric coloring materials and investigates more particularly their provenance. She carried out this investigation in the decorated cave from the Paleolithic, the Grotte aux Points (Ardèche) both on the archaeological artefacts and on the paints.

\section{Aurélie Chassin de Kergommeaux}

PhD student in the EDYTEM laboratory at the University of Savoie Mont Blanc, A. Chassin de Kergommeaux studies the spatial and compositional trajectories of iron-rich coloring matter. She carries out this investigation through the study of archaeological artefacts from paleolithic sites and their geological equivalent (coming from primary and secondary positions) in the Yonne catchment area.

\section{Fayçal Soufi}

Assistant engineer at the Université Savoie Mont Blanc (Platform ASTRE), Fayçal Soufi is a specialist in the classical preparation of thin sections of rock but also of sedimentary 
cores, soils and archaeological materials. He also adapts methods for the preparation of polished studs and enresined objects.

\section{Hélène Salomon}

Researcher CNRS and Université Savoie Mont Blanc (EDYTEM laboratory), H. Salomon is a prehistorian. She developed research on prehistoric coloring materials since her PhD (PACEA and C2RMF). Her fieldworks are mainly situated in France and concern open air sites (Ormesson, Régismont-le-Haut, Pincevent), rock shelters as well as rock art caves (Lascaux, Chauvet, Cussac). 
TABLE

\begin{tabular}{|c|c|c|c|}
\hline $\begin{array}{l}\text { Sample } \\
\text { location }\end{array}$ & ID (ex) & Micro-morphology & Mineralogy \\
\hline $\begin{array}{l}\text { Pierremort } \\
\text { e }\end{array}$ & $\begin{array}{l}\text { PIG_0159 } \\
(2016-026)\end{array}$ & $\begin{array}{l}\text { Partly ferruginised crinoid } \\
\text { fragments in a ferruginised } \\
\text { carbonated matrix }\end{array}$ & $\begin{array}{l}\text { Hematite, calcite, } \\
\text { quartz }\end{array}$ \\
\hline Bordezac & $\begin{array}{l}\text { PIG_0160 } \\
(2016-027)\end{array}$ & $\begin{array}{l}\text { Metallic vein composed of } \\
\text { hematite and rare tabular } \\
\text { micas }(100 \mu \mathrm{m}) \text { and quartz } \\
\text { in microfissures }\end{array}$ & $\begin{array}{l}\text { Hematite, micas, } \\
\text { quartz, xenotime- } \\
(Y), \text { baryte }\end{array}$ \\
\hline Huy & $\begin{array}{l}\text { PIG_0172 } \\
(2016-021)\end{array}$ & $\begin{array}{l}\text { Well sorted flax seeds } \\
\text { ooids with bioclastic, } \\
\text { quartz }(100 \mu \mathrm{m}) \text { or rare } \\
\text { lithoclastic nuclei }\end{array}$ & $\begin{array}{l}\text { Hematite, kaolinite, } \\
\text { quartz, goethite, } \\
\text { calcite, dolomite, } \\
\text { chlorite, siderite, } \\
\text { calcium phosphate, } \\
\text { baryte }\end{array}$ \\
\hline Roussillon & $\begin{array}{l}\text { PIG_0173 } \\
(2016-022)\end{array}$ & $\begin{array}{l}\text { More or less corroded } \\
\text { quartz grains ( } 200-400 \\
\mu \mathrm{m}) \text { in an iron-rich clayey } \\
\text { matrix }\end{array}$ & $\begin{array}{l}\text { Hematite, } \\
\text { kaolinite, quartz, } \\
\text { goethite, zircon }\end{array}$ \\
\hline $\begin{array}{l}\text { Beauregar } \\
\text { d }\end{array}$ & $\begin{array}{l}\text { PIG_0174 } \\
(2016-023)\end{array}$ & $\begin{array}{l}\text { Entirely ferruginised } \\
\text { crinoid fragments ( } 3 \mathrm{~mm} \text { ) } \\
\text { in a hematite-rich cement }\end{array}$ & $\begin{array}{l}\text { Hematite, goethite, } \\
\text { baryte }\end{array}$ \\
\hline Pierrerue & $\begin{array}{l}\text { PIG_0176 } \\
(2016-025)\end{array}$ & $\begin{array}{l}\text { Ferruginous pisoliths } \\
\text { visible to the naked eye, } \\
\text { hematite ball in hexagonal } \\
\text { plates }(10 \mu \mathrm{m}) \text { and } \\
\text { kaolinite accordions }(<5 \\
\mu \mathrm{m})\end{array}$ & $\begin{array}{l}\text { Kaolinite, } \\
\text { hematite, calcite, } \\
\text { goethite, alumina } \\
\text { minerals }\end{array}$ \\
\hline
\end{tabular}


Table 1 : Summarized petrological descriptions, SEM-EDX and XRD results obtained for the standards samples (Major (>20\%), minor, traces - not identified by XRD (<3\%) but identified with SEM-EDX)

\section{FIGURE CAPTIONS}

Figure 1: Location of the outcrops of the 6 reference samples (Huy in yellow; Beauregard in grey; Bordezac in green; Pierremorte in blue; Roussillon in red; Pierrerue in pink; modified from the BRGM vector geological map at 1:50,000 superimposed on the IGN's topographical map, cf. infoterre to have the complete legend).

Figure 2: Polished cross section pictures: A) Huy (Oolitic Iron Stone), B) Pierrerue (iron duricrust in a bauxitic profile), C) Pierremorte (partly ferruginised crinoid-rich limestone), D) Roussillon (ferricrete fragment from ochre profile), E) Beauregard (entirely ferruginised crinoid-rich limestone), F) Bordezac (hematite-rich hydrothermal metallic vein)

Figure 3: Painting of 5 of the standard pigments on porous limestone (A: Bordezac, B: Pierremorte, D: Roussillon, E: Huy, G: Pierrerue) and Valaurie and Huy pigments on less porous limestone (the group of red dots is the measurement spots).

Figure 4: Example of typical and extreme corrections of atmospheric water vapor fluctuation by dividing the spectrum by a scaled water vapor transmission spectrum measured with the same instrument parameters. The scaling factor $f$ is adjusted for each spectrum to cancel the narrow spectral lines of water vapor. These spectra are those presented in Fig. 9a, except the last one (> $400 \mu \mathrm{m})$ which did not need correction (measured just after the reference).

Figure 5: SEM pictures (back scattering electron (BSE) mode and chemical mapping). 1-2) Huy: oolith iron stone: 1 ) Oo: ferruginous ooliths, e: calcium phosphate and carbonate crinoid coated by hematite, pe: peloid coated by hematite, $\mathrm{m}$ : dolomite and ferruginous clayey matrix and cement; 2) chemical mapping showing ferruginous (red) and calcium phosphate (dark and light blue) laminations within the oolith, calcium carbonate and phosphate skeleton of crinoid (dark and light blue), calcium carbonates in the cement (dark blue), and ferruginous clayey matrix (Si yellow). 3-4) Pierremorte: ferruginised limestone: 3) Ca: calcite, Fe: hematite, e: crinoid, s: urchin spicule; 4) chemical mapping showing ferruginised crinoids (red), calcite matrix (blue, m) and quartz grain (yellow, Q). 5-6) Beauregard: 9) crinoid ghosts (e) replaced by iron oxides (Fe); 10) baryte (Ba) hydrothermal veinlet within a crinoid ghost (e). 11-12) Pierrerue: 11) Iron duricrust in bauxite with mainly hematite $(\mathrm{Fe}) ; 12)$ alumino-silicate with high aluminium content $(\mathrm{Al}, \mathrm{Si})$ surrounded by hematite (hem) and the pore coated with goethite (goe). 7-8) Pierrerue: 7) Iron duricrust in bauxite with mainly hematite (Fe); 8 ) alumino-silicate with high aluminium content 
(Al,Si) surrounded by hematite (hem) and the pore coated with goethite (goe). 9-10) Roussillon: iron duricrust: 9) Q: quartz grain, m: clayey ferruginous matrix containing kaolinite (K), Fe: iron oxide coating along a quartz grain; 10) Zr: zircon grains within a quartz grain (Q). 11-12) Bordezac: hydrothermal hematite. 11) Fe: hematite, Mi: mica, Ba: baryte. 12) Fe: hematite matrix, Mi: altered micas and $\mathrm{Y}$ : xenotime grain.

Figure 6: Vis-NIR reflectance spectra of powders of the 6 reference samples: Pierremorte, Bordezac, Roussillon, Huy, Beauregard, and Pierrerue (powders with grain size $<160 \mu \mathrm{m}$ ).

Figure 7: Vis-NIR reflectance spectra of the major and some of the minor minerals constituting the six standard pigments. The hematite, kaolinite, quartz and calcite spectra are from IPAG, goethite, baryte and chlorite from the USGS spectral library (https://crustal.usgs.gov/speclab/QueryAll07a.php), dolomite and muscovite from the RELAB database of the PDS Geosciences Node Spectral Library (https://pds-speclib.rsl.wustl.edu).

Figure 8: Vis-NIR reflectance spectra of the 6 standards, Beauregard, Bordezac, Huy, Pierremorte, Roussillon and Pierrerue with different textures: powders (with different grain sizes or densities, blocks (raw, fresh fracture or sawn face) and a polished plot.

Figure 9: Vis-NIR reflectance spectra of (a) Roussillon and (b) Huy powders with 4 different grain size ranges: $<50 \mu \mathrm{m}, 100-200 \mu \mathrm{m}, 200-400 \mu \mathrm{m},>400 \mu \mathrm{m}$.

Figure 10: Comparison between the Vis-NIR reflectance spectra of the powder (grain size $<160$ $\mu \mathrm{m}$ ) and the most different raw block (dotted lines) for Bordezac, Huy, Pierremorte, and Pierrerue.

Figure 11: Vis-NIR reflectance spectra of polished plots of the 6 reference samples: Pierremorte, Bordezac, Roussillon, Huy, Beauregard, Pierrerue (Fig. 2). These spectra can be compared with the ones of powders (Fig. 5). Pierremorte and Roussillon display additional absorptions, not yet identified.

Figure 12: Vis-NIR reflectance spectra of 4 painting matters deposited on a limestone substrate (dotted lines, pictures in Fig. 4) compared to their corresponding powder spectrum (grain size < $160 \mu \mathrm{m}$, full lines). The spectrum of the bare limestone substrate is also shown (grey). Bordezac and Huy are not shown as they are very opaque with almost the same spectra except the 2 carbonate bands around 3500 and $4000 \mathrm{~nm}$.

Figure 13: Vis-NIR reflectance spectra of a) 3 different thicknesses of Huy paint on a calcite slice, b) 4 different thicknesses of Valaurie (an ochre of Roussillon type, PIG-0204-2018) paint on a calcite slice (orange-red colors). The spectrum of the powders ( $<160 \mu \mathrm{m}$, blue) used to prepare the paints and of the bare calcite slice (black) are also shown.

Figure 14: Vis-NIR reflectance spectra of a layer of a paint made with an ochre of Roussillon type: Valaurie pigment (PIG-0204-2018) on a calcite slice at 3 very different geometries (i: illumination 
angle, e: observation angle. $0^{\circ}$ is at nadir). The spectrum of the Valaurie powder ( $<160 \mu \mathrm{m}$, blue) used to prepare the paint and of the bare calcite slice (black) are also shown. 


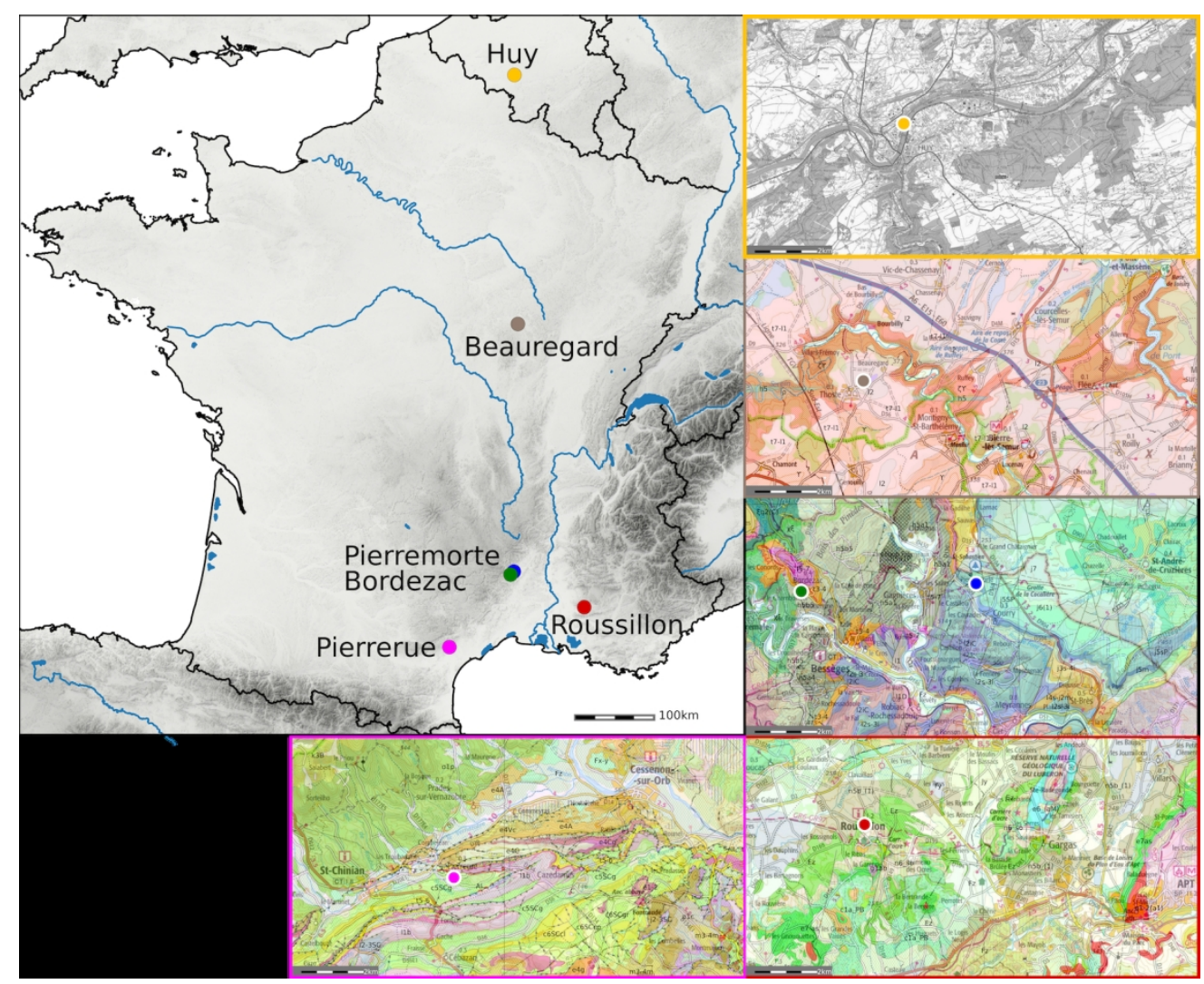

Figure 1: Location of the outcrops of the 6 reference samples (Huy in yellow; Beauregard in grey; Bordezac in green; Pierremorte in blue; Roussillon in red; Pierrerue in pink; modified from the BRGM vector geological map at 1:50,000 superimposed on the IGN's topographical map, cf. infoterre to have the complete legend).

$150 \times 122 \mathrm{~mm}(300 \times 300 \mathrm{DPI})$ 


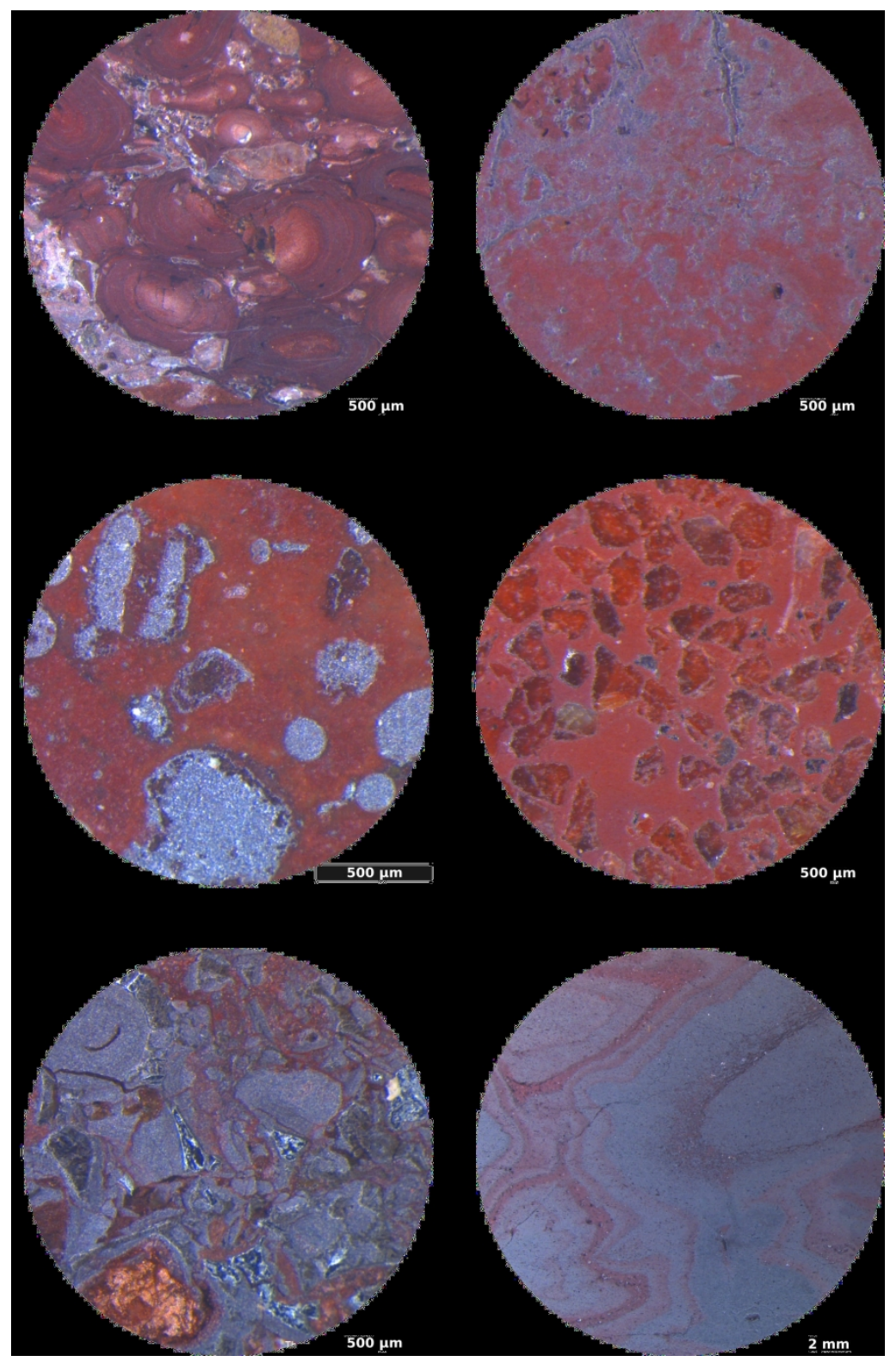

Figure 2: Polished cross section pictures: A) Huy (Oolitic Iron Stone), B) Pierrerue (iron duricrust in a bauxitic profile), C) Pierremorte (partly ferruginised crinoid-rich limestone), D) Roussillon (ferricrete fragment from ochre profile), E) Beauregard (entirely ferruginised crinoid-rich limestone), F) Bordezac (hematite-rich hydrothermal metallic vein) 


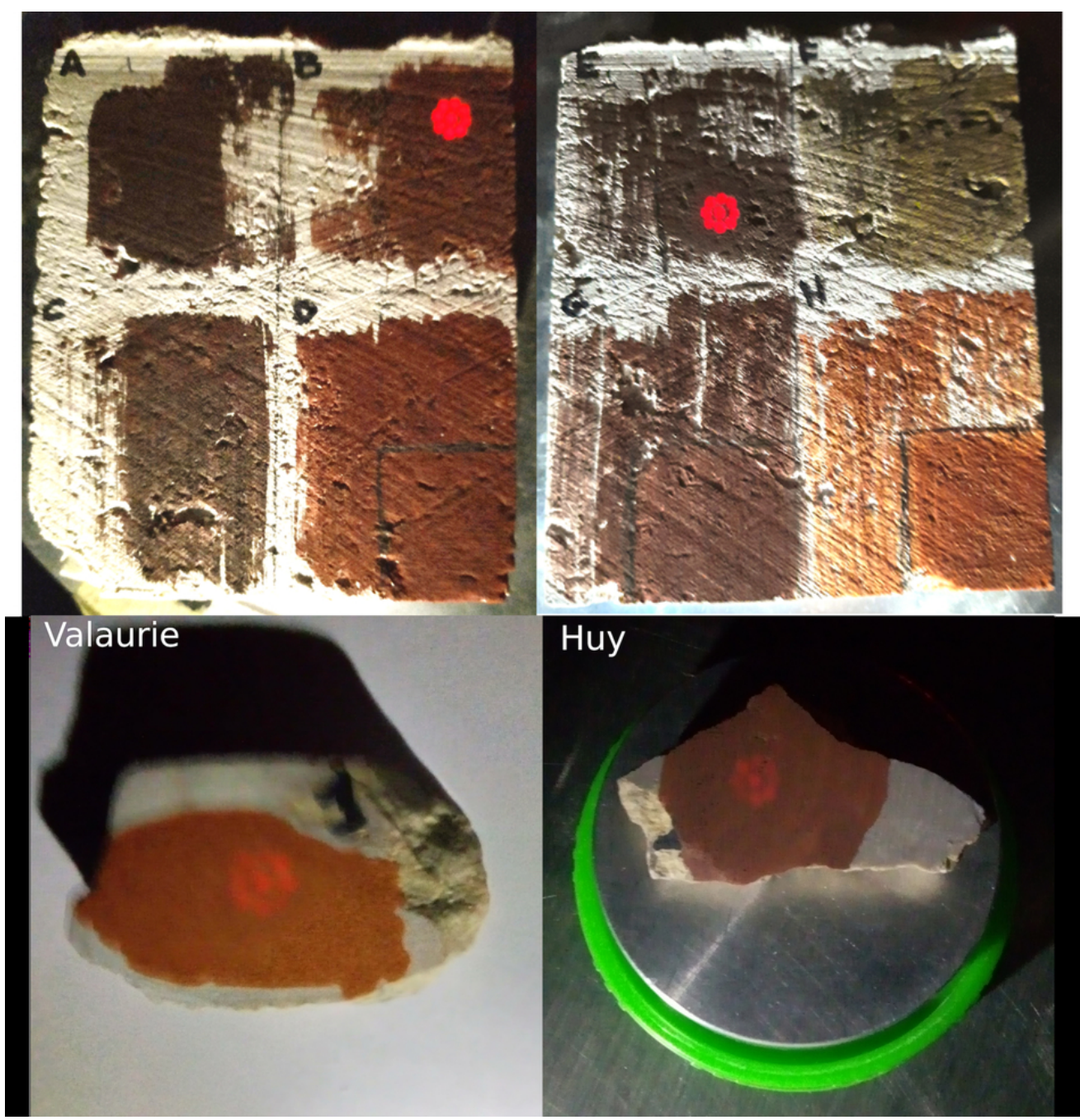

Figure 3: Painting of 5 of the standard pigments on porous limestone (A: Bordezac, B: Pierremorte, D: Roussillon, E: Huy, G: Pierrerue) and Valaurie and Huy pigments on less porous limestone (the group of red dots is the measurement spots).

$80 \times 82 \mathrm{~mm}(300 \times 300 \mathrm{DPI})$ 


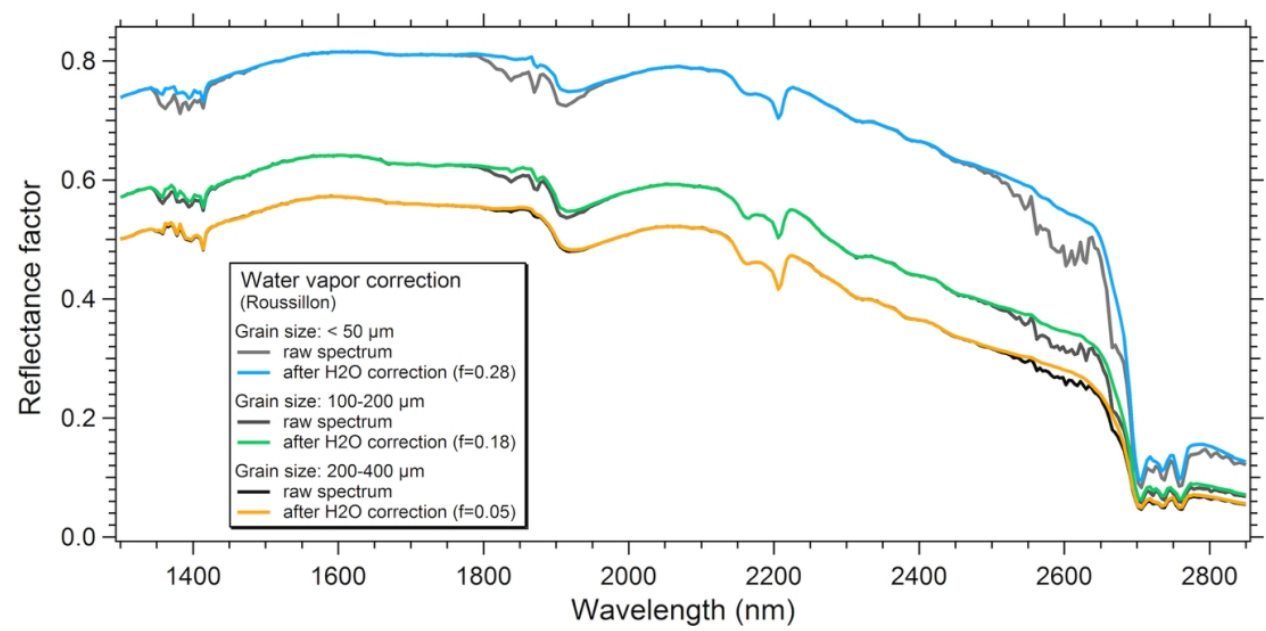

Figure 4: Example of typical and extreme corrections of atmospheric water vapor fluctuation by dividing the spectrum by a scaled water vapor transmission spectrum measured with the same instrument parameters. The scaling factor $\mathrm{f}$ is adjusted for each spectrum to cancel the narrow spectral lines of water vapor. These spectra are those presented in Fig. 9a, except the last one $(>400 \mu \mathrm{m})$ which did not need correction (measured just after the reference).

$119 \times 57 \mathrm{~mm}(300 \times 300$ DPI $)$ 


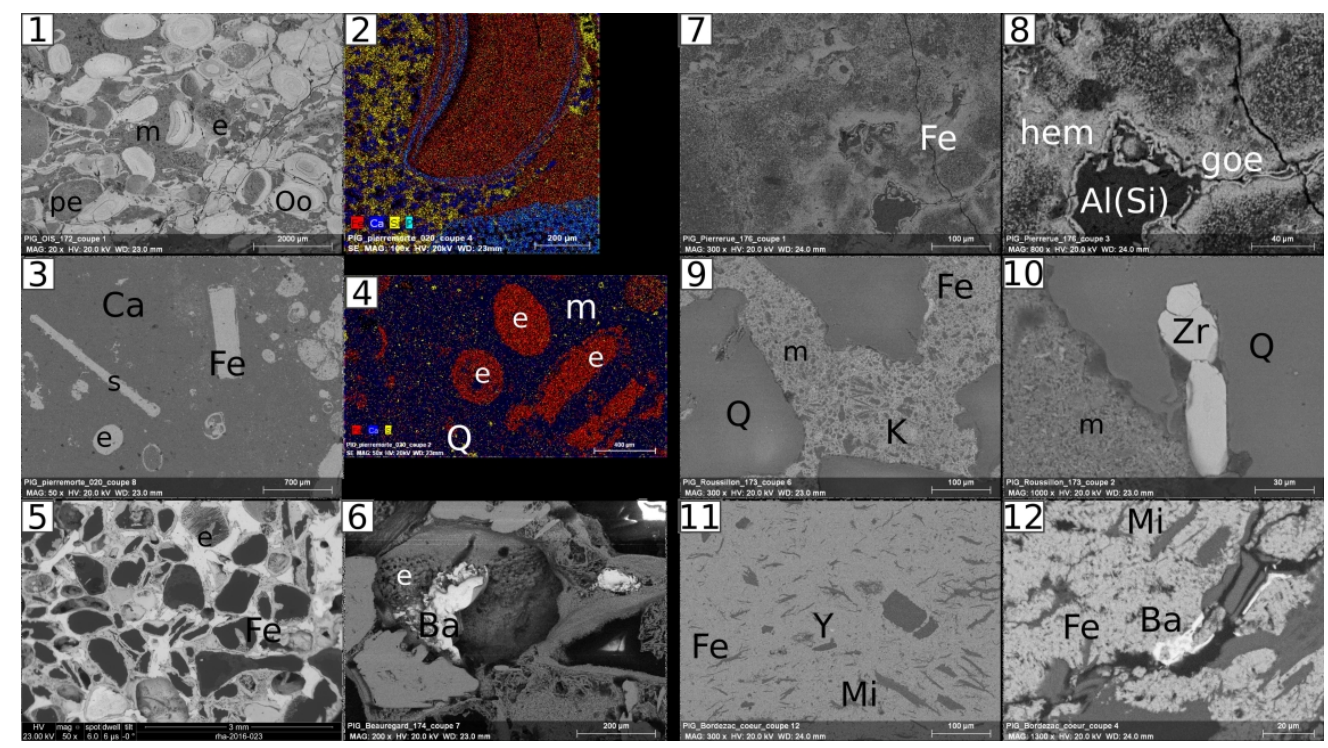

Figure 5: SEM pictures (back scattering electron (BSE) mode and chemical mapping). 1-2) Huy: oolith iron stone: 1) Oo: ferruginous ooliths, e: calcium phosphate and carbonate crinoid coated by hematite, pe: peloid coated by hematite, $\mathrm{m}$ : dolomite and ferruginous clayey matrix and cement; 2) chemical mapping showing ferruginous (red) and calcium phosphate (dark and light blue) laminations within the oolith, calcium carbonate and phosphate skeleton of crinoid (dark and light blue), calcium carbonates in the cement (dark blue), and ferruginous clayey matrix (Si yellow). 3-4) Pierremorte: ferruginised limestone: 3) Ca: calcite, Fe: hematite, e: crinoid, s: urchin spicule; 4) chemical mapping showing ferruginised crinoids (red), calcite matrix (blue, m) and quartz grain (yellow, Q). 5-6) Beauregard: 9) crinoid ghosts (e) replaced by iron oxides (Fe); 10) baryte (Ba) hydrothermal veinlet within a crinoid ghost (e). 11-12) Pierrerue: 11) Iron duricrust in bauxite with mainly hematite $(\mathrm{Fe}) ; 12$ ) alumino-silicate with high aluminium content $(\mathrm{Al}, \mathrm{Si})$ surrounded by hematite (hem) and the pore coated with goethite (goe). 7-8) Pierrerue: 7) Iron duricrust in bauxite with mainly hematite $(\mathrm{Fe}) ; 8$ ) alumino-silicate with high aluminium content (Al,Si) surrounded by hematite (hem) and the pore coated with goethite (goe). 9-10) Roussillon: iron duricrust: 9) Q: quartz grain, $\mathrm{m}$ : clayey ferruginous matrix containing kaolinite (K), Fe: iron oxide coating along a quartz grain; 10) Zr: zircon grains within a quartz grain (Q). 11-12) Bordezac: hydrothermal hematite. 11) Fe: hematite, Mi: mica, Ba: baryte. 12) Fe: hematite matrix, Mi: altered micas and Y: xenotime grain. 


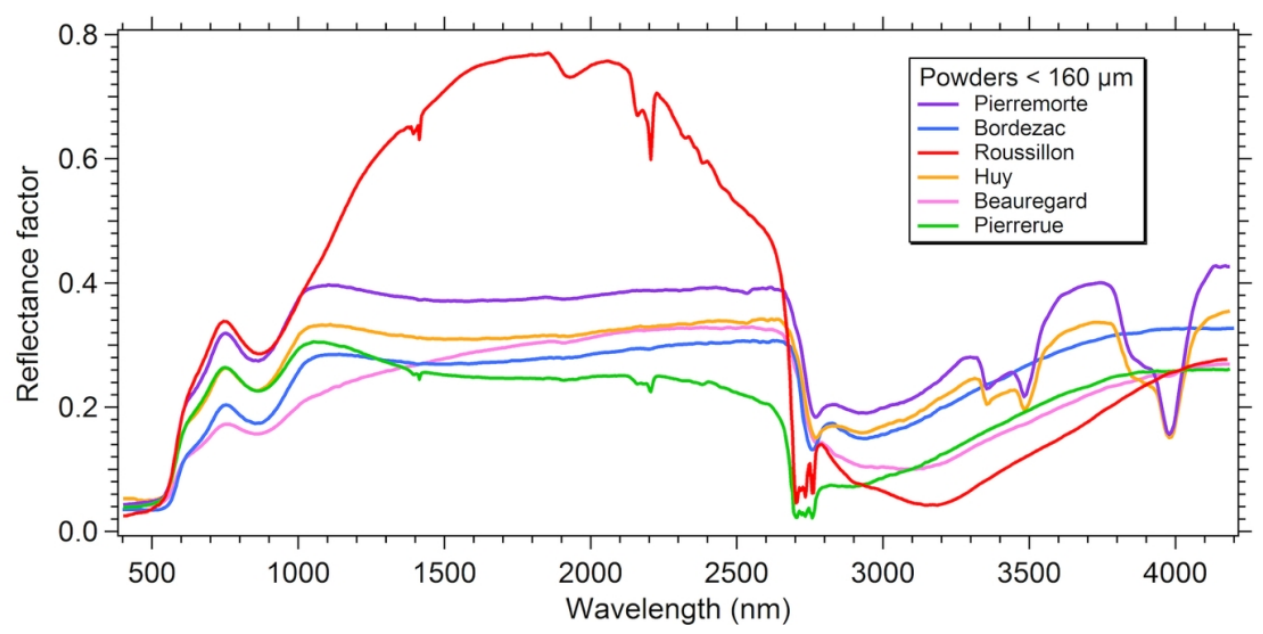

Figure 6: Vis-NIR reflectance spectra of powders of the 6 reference samples: Pierremorte, Bordezac, Roussillon, Huy, Beauregard, and Pierrerue (powders with grain size $<160 \mu \mathrm{m}$ ).

$119 \times 57 \mathrm{~mm}(300 \times 300 \mathrm{DPI})$ 


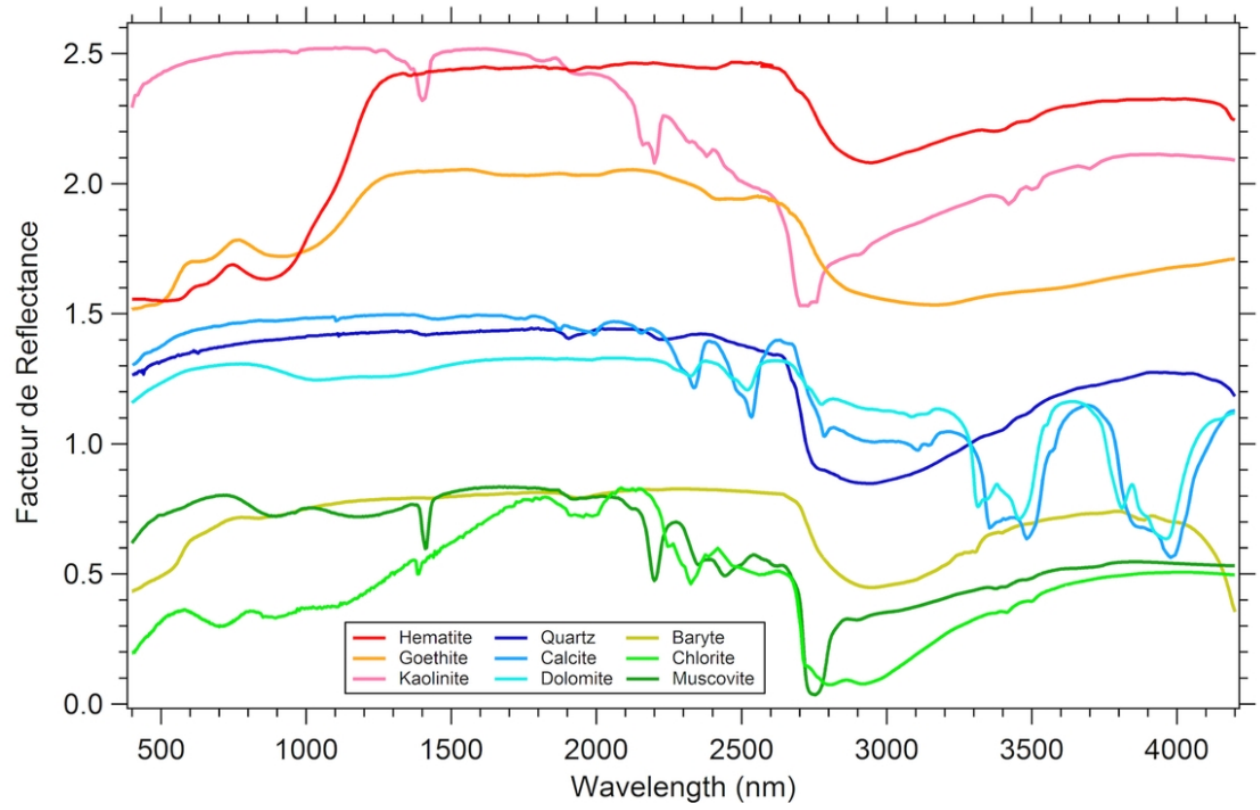

Figure 7: Vis-NIR reflectance spectra of the major and some of the minor minerals constituting the six standard pigments. The hematite, kaolinite, quartz and calcite spectra are from IPAG, goethite, baryte and chlorite from the USGS spectral library (https://crustal.usgs.gov/speclab/QueryAll07a.php), dolomite and muscovite from the RELAB database of the PDS Geosciences Node Spectral Library (https://pdsspeclib.rsl.wustl.edu).

$99 \times 62 \mathrm{~mm}(300 \times 300 \mathrm{DPI})$ 


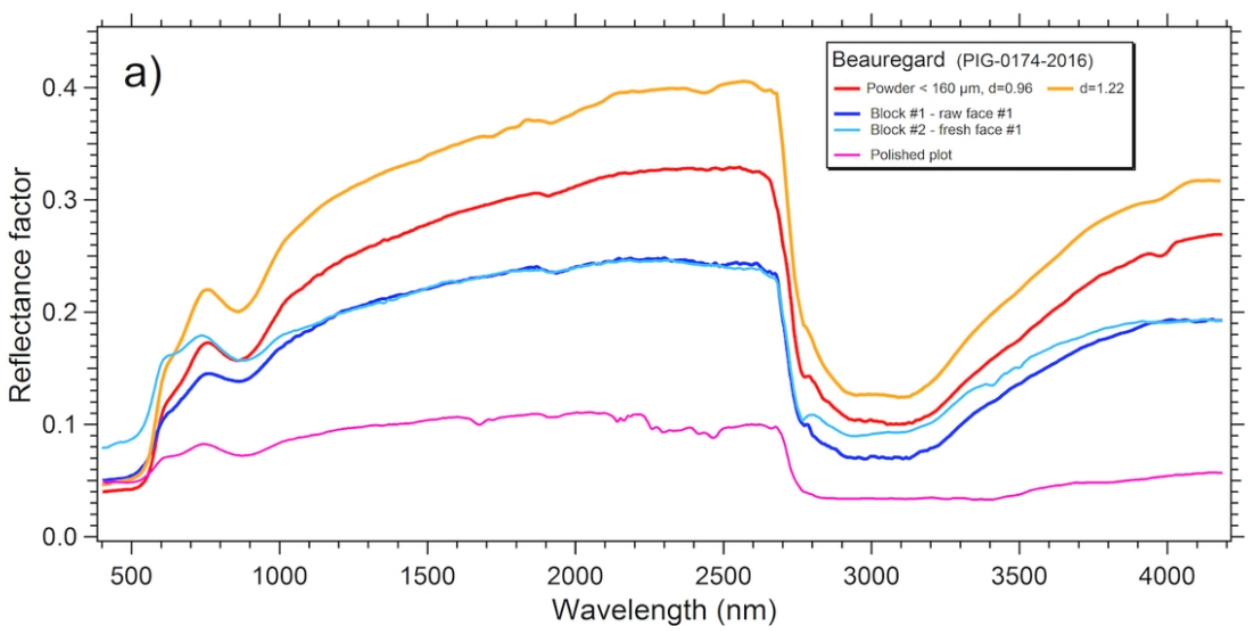

Figure 8: Vis-NIR reflectance spectra of the 6 standards, Beauregard, Bordezac, Huy, Pierremorte, Roussillon and Pierrerue with different textures: powders (with different grain sizes or densities, blocks (raw, fresh fracture or sawn face) and a polished plot.

$99 \times 47 \mathrm{~mm}(300 \times 300 \mathrm{DPI})$ 


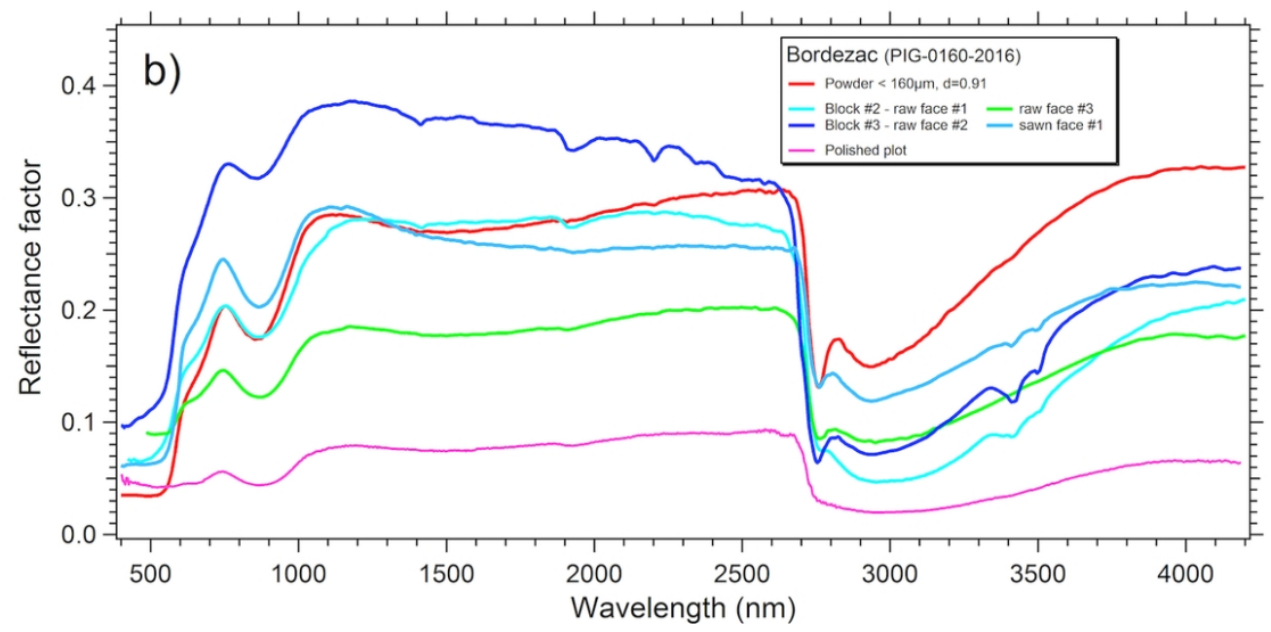

Figure 8: Vis-NIR reflectance spectra of the 6 standards, Beauregard, Bordezac, Huy, Pierremorte, Roussillon and Pierrerue with different textures: powders (with different grain sizes or densities, blocks (raw, fresh fracture or sawn face) and a polished plot.

$99 \times 47 \mathrm{~mm}(300 \times 300 \mathrm{DPI})$ 


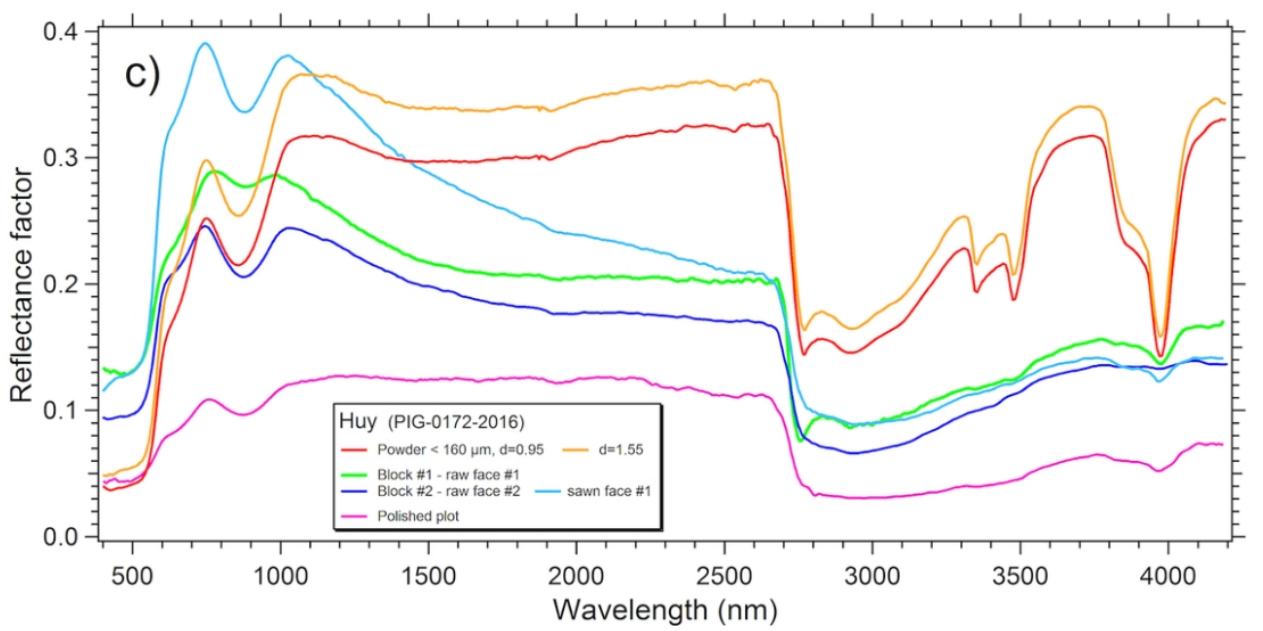

Figure 8: Vis-NIR reflectance spectra of the 6 standards, Beauregard, Bordezac, Huy, Pierremorte, Roussillon and Pierrerue with different textures: powders (with different grain sizes or densities, blocks (raw, fresh fracture or sawn face) and a polished plot.

$99 \times 47 \mathrm{~mm}(300 \times 300 \mathrm{DPI})$ 


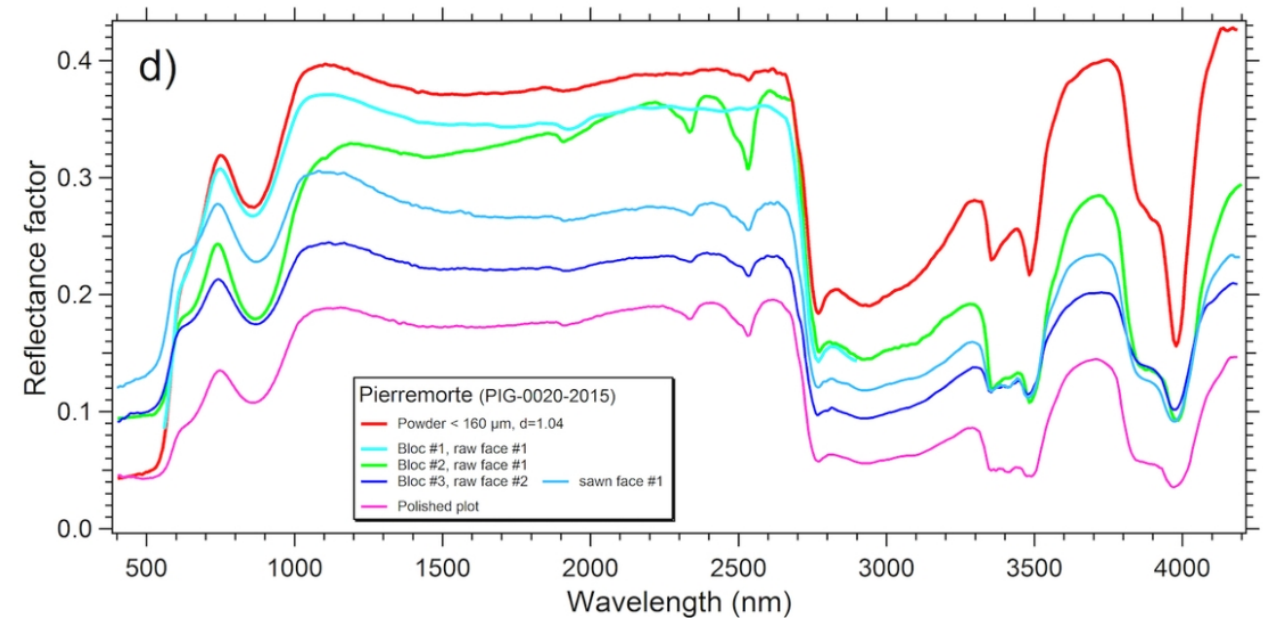

Figure 8: Vis-NIR reflectance spectra of the 6 standards, Beauregard, Bordezac, Huy, Pierremorte, Roussillon and Pierrerue with different textures: powders (with different grain sizes or densities, blocks (raw, fresh fracture or sawn face) and a polished plot.

$99 \times 47 \mathrm{~mm}(300 \times 300$ DPI $)$ 


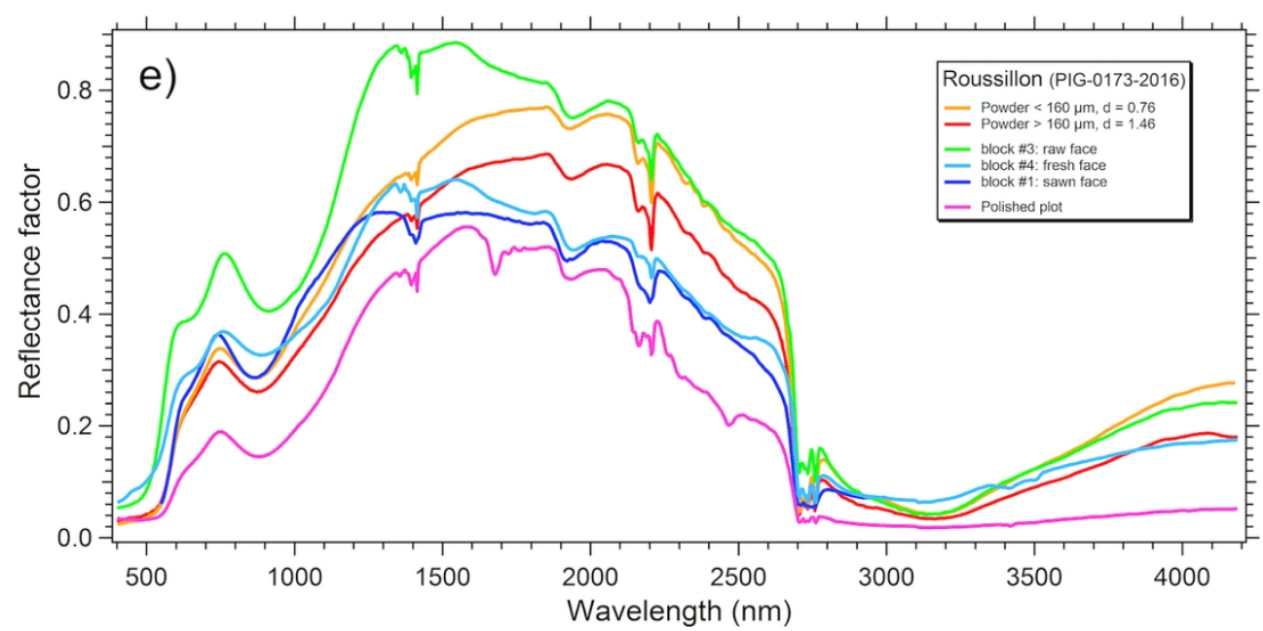

Figure 8: Vis-NIR reflectance spectra of the 6 standards, Beauregard, Bordezac, Huy, Pierremorte, Roussillon and Pierrerue with different textures: powders (with different grain sizes or densities, blocks (raw, fresh fracture or sawn face) and a polished plot.

$99 \times 47 \mathrm{~mm}(300 \times 300 \mathrm{DPI})$ 


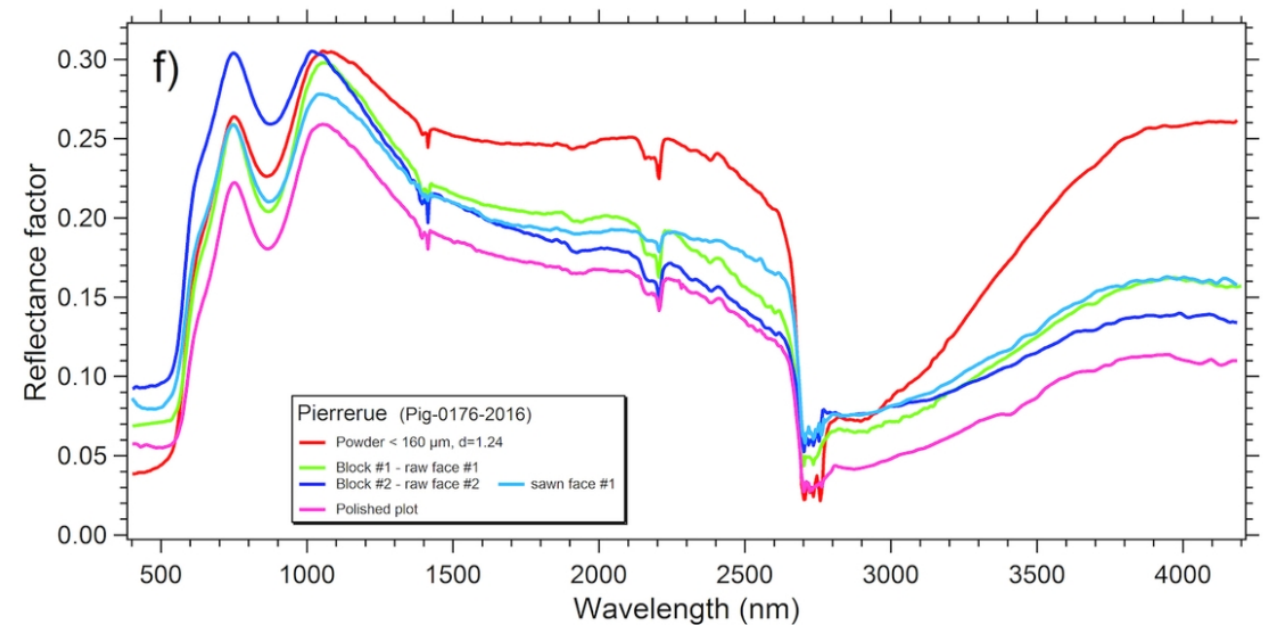

Figure 8: Vis-NIR reflectance spectra of the 6 standards, Beauregard, Bordezac, Huy, Pierremorte, Roussillon and Pierrerue with different textures: powders (with different grain sizes or densities, blocks (raw, fresh fracture or sawn face) and a polished plot.

$99 \times 48 \mathrm{~mm}(300 \times 300$ DPI $)$ 


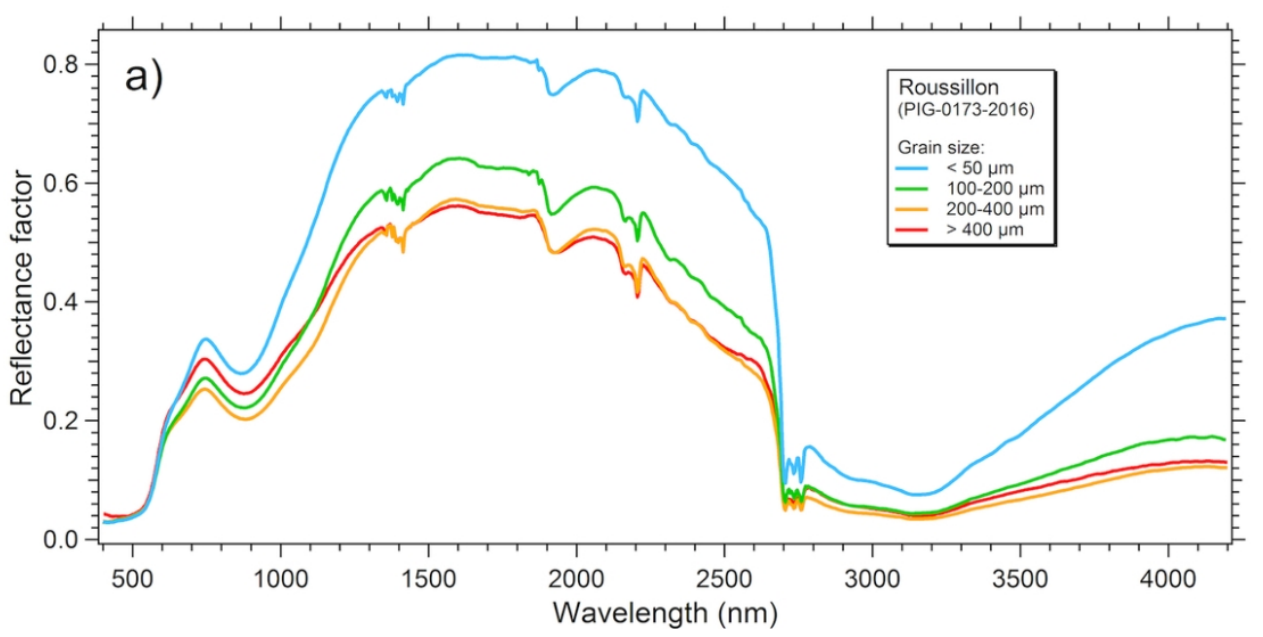

Figure 9: Vis-NIR reflectance spectra of (a) Roussillon and (b) Huy powders with 4 different grain size ranges: $<50 \mu \mathrm{m}, 100-200 \mu \mathrm{m}, 200-400 \mu \mathrm{m},>400 \mu \mathrm{m}$.

$99 \times 47 \mathrm{~mm}(300 \times 300 \mathrm{DPI})$ 


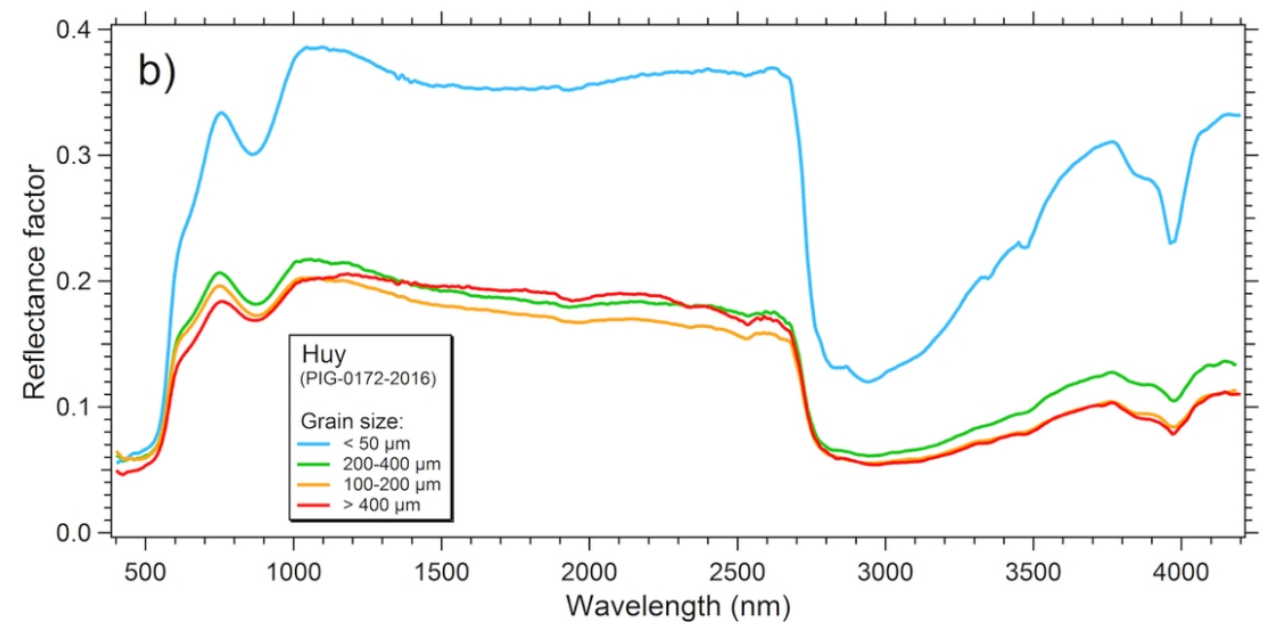

Figure 9: Vis-NIR reflectance spectra of (a) Roussillon and (b) Huy powders with 4 different grain size ranges: $<50 \mu \mathrm{m}, 100-200 \mu \mathrm{m}, 200-400 \mu \mathrm{m},>400 \mu \mathrm{m}$.

$99 \times 47 \mathrm{~mm}(300 \times 300 \mathrm{DPI})$ 


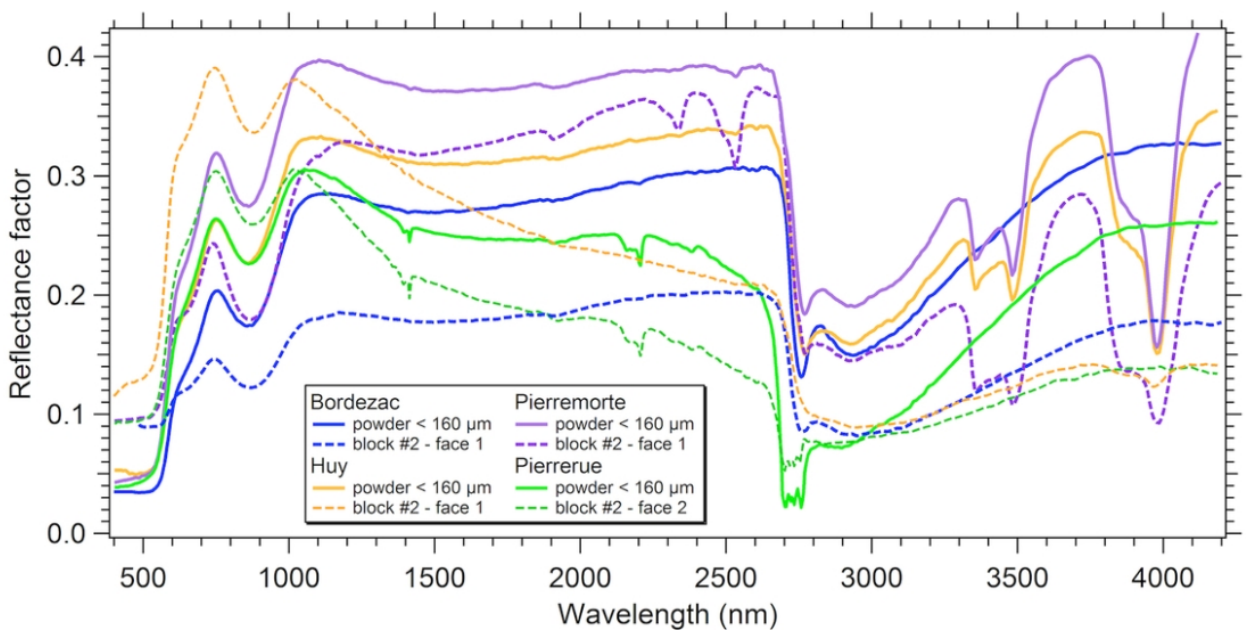

Figure 10: Comparison between the Vis-NIR reflectance spectra of the powder (grain size $<160 \mu \mathrm{m}$ ) and the most different raw block (dotted lines) for Bordezac, Huy, Pierremorte, and Pierrerue.

\section{$99 \times 48 \mathrm{~mm}(300 \times 300 \mathrm{DPI})$}




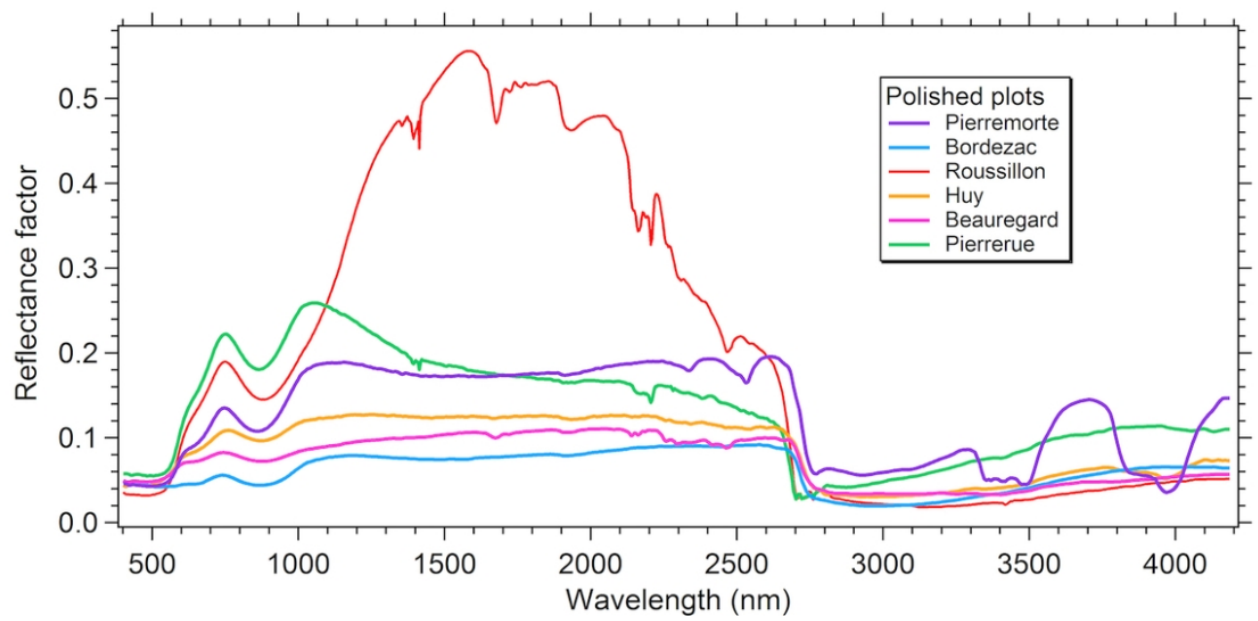

Figure 11: Vis-NIR reflectance spectra of polished plots of the 6 reference samples: Pierremorte, Bordezac, Roussillon, Huy, Beauregard, Pierrerue (Fig. 2). These spectra can be compared with the ones of powders (Fig. 5). Pierremorte and Roussillon display additional absorptions, not yet identified.

$99 \times 47 \mathrm{~mm}(300 \times 300 \mathrm{DPI})$ 


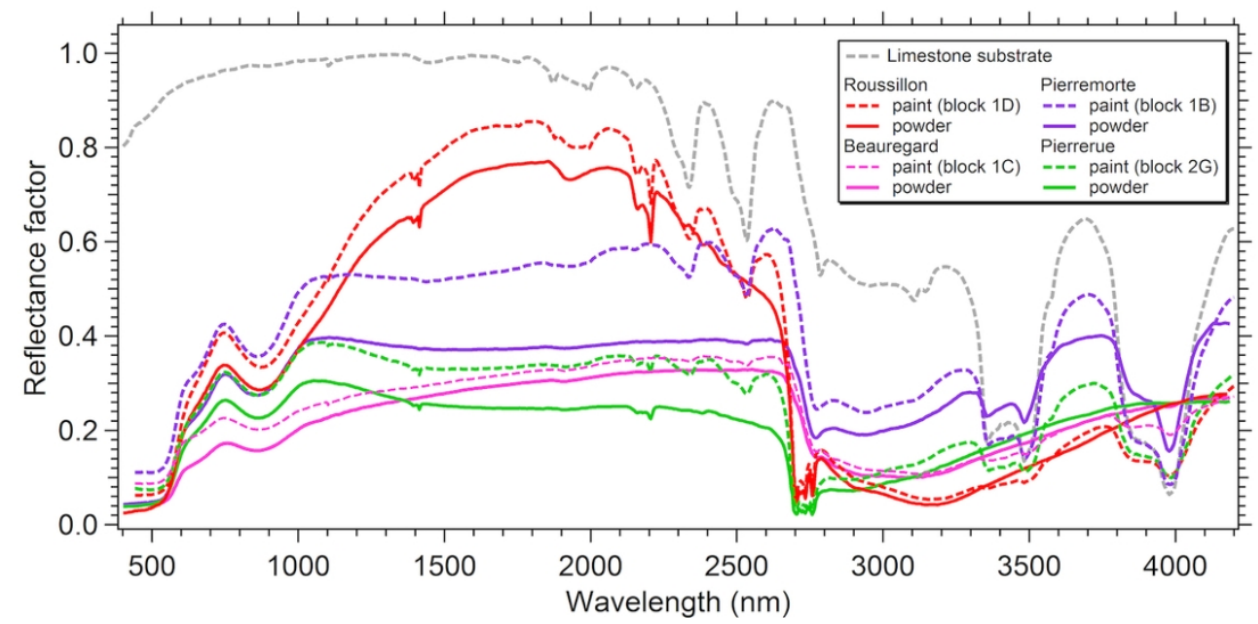

Figure 12: Vis-NIR reflectance spectra of 4 painting matters deposited on a limestone substrate (dotted lines, pictures in Fig. 4) compared to their corresponding powder spectrum (grain size $<160 \mu \mathrm{m}$, full lines). The spectrum of the bare limestone substrate is also shown (grey). Bordezac and Huy are not shown as they are very opaque with almost the same spectra except the 2 carbonate bands around 3500 and 4000 $\mathrm{nm}$.

$99 \times 47 \mathrm{~mm}(300 \times 300 \mathrm{DPI})$ 


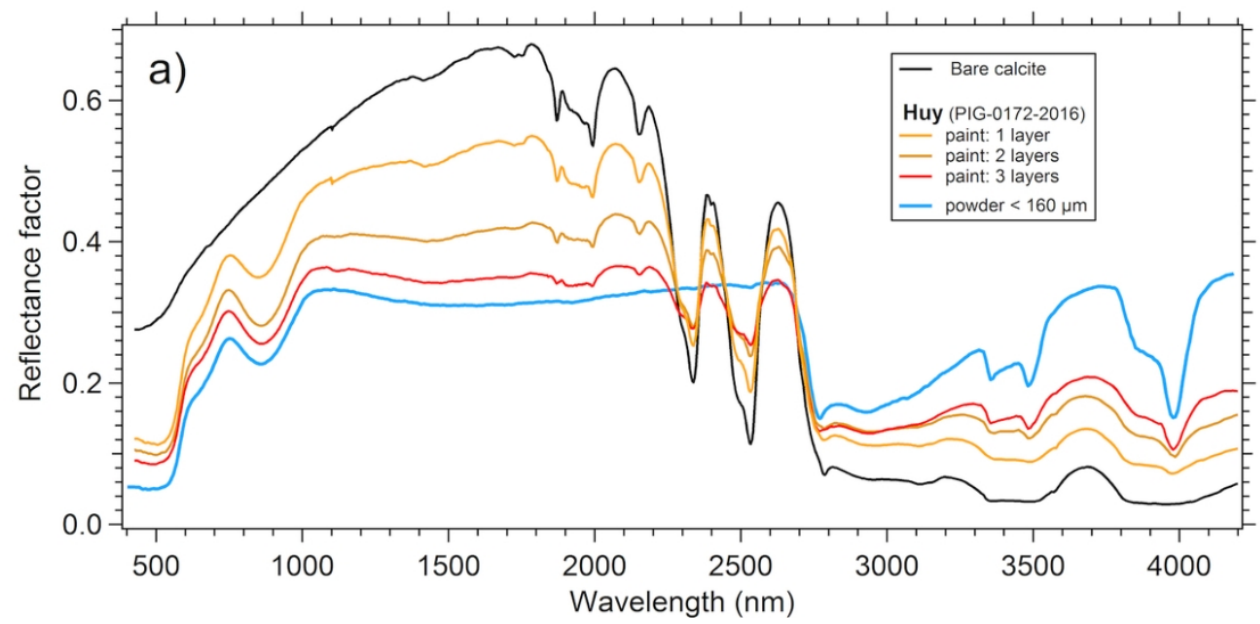

Figure 13: Vis-NIR reflectance spectra of a) 3 different thicknesses of Huy paint on a calcite slice, b) 4 different thicknesses of Valaurie (an ochre of Roussillon type, PIG-0204-2018) paint on a calcite slice (orange-red colors). The spectrum of the powders $(<160 \mu \mathrm{m}$, blue) used to prepare the paints and of the bare calcite slice (black) are also shown.

$99 \times 47 \mathrm{~mm}(300 \times 300 \mathrm{DPI})$ 


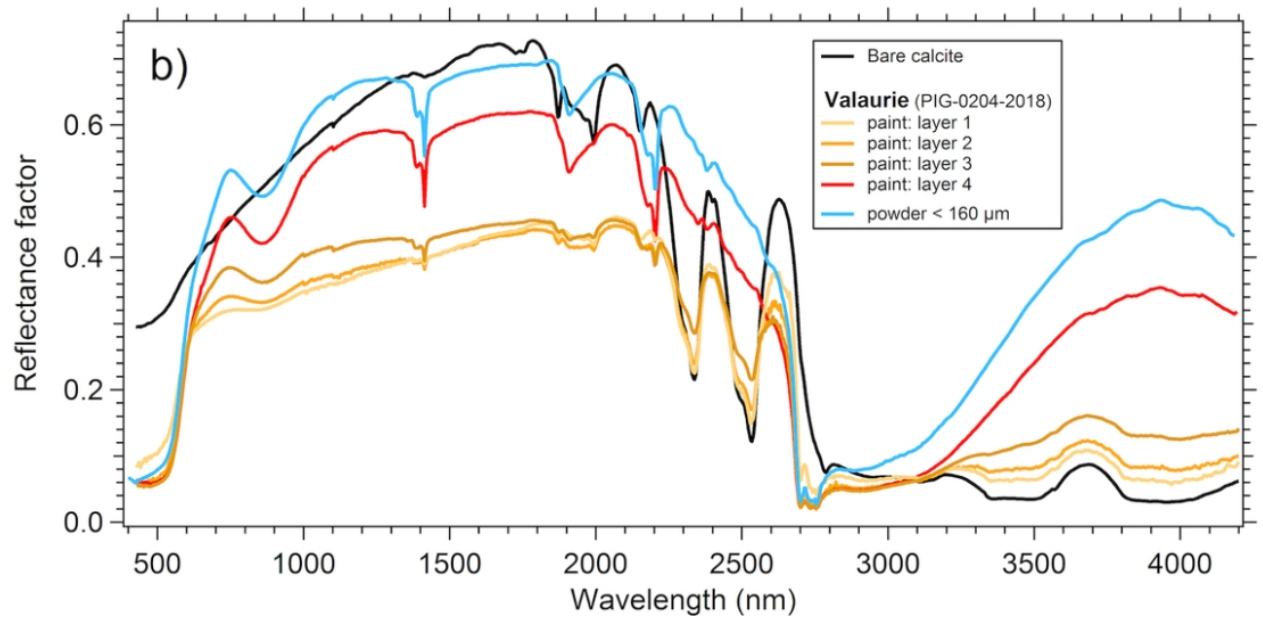

Figure 13: Vis-NIR reflectance spectra of a) 3 different thicknesses of Huy paint on a calcite slice, b) 4 different thicknesses of Valaurie (an ochre of Roussillon type, PIG-0204-2018) paint on a calcite slice (orange-red colors). The spectrum of the powders $(<160 \mu \mathrm{m}$, blue) used to prepare the paints and of the bare calcite slice (black) are also shown.

$99 \times 47 \mathrm{~mm}(300 \times 300 \mathrm{DPI})$ 
Figure 14: Vis-NIR reflectance spectra of a layer of a paint made with an ochre of Roussillon type: Valaurie pigment (PIG-0204-2018) on a calcite slice at 3 very different geometries (i: illumination angle, e: observation angle. $0^{\circ}$ is at nadir). The spectrum of the Valaurie powder $(<160 \mu \mathrm{m}$, blue) used to prepare the paint and of the bare calcite slice (black) are also shown.

\section{$99 \times 47 \mathrm{~mm}(300 \times 300$ DPI $)$}




\begin{tabular}{|c|c|c|c|}
\hline $\begin{array}{l}\text { Sample } \\
\text { location }\end{array}$ & ID (ex) & Micro-morphology & Mineralogy \\
\hline Pierremorte & $\begin{array}{l}\text { PIG_0159 } \\
(2016-026)\end{array}$ & $\begin{array}{l}\text { Partly ferruginised crinoid } \\
\text { fragments in a ferruginised } \\
\text { carbonated matrix }\end{array}$ & $\begin{array}{l}\text { Hematite, calcite, } \\
\text { quartz }\end{array}$ \\
\hline Bordezac & $\begin{array}{l}\text { PIG_0160 } \\
(2016-027)\end{array}$ & $\begin{array}{l}\text { Metallic vein composed of } \\
\text { hematite and rare tabular } \\
\text { micas ( } 100 \mu \mathrm{m}) \text { and quartz in } \\
\text { microfissures }\end{array}$ & $\begin{array}{l}\text { Hematite, micas, } \\
\text { quartz, xenotime- }(Y) \text {, } \\
\text { baryte }\end{array}$ \\
\hline Huy & $\begin{array}{l}\text { PIG_0172 } \\
(2016-021)\end{array}$ & $\begin{array}{l}\text { Well sorted flax seeds ooids } \\
\text { with bioclastic, quartz ( } 100 \\
\mu \mathrm{m} \text { ) or rare lithoclastic nuclei }\end{array}$ & $\begin{array}{l}\text { Hematite, kaolinite, } \\
\text { quartz, goethite, } \\
\text { calcite, dolomite, } \\
\text { chlorite, siderite, } \\
\text { calcium phosphate, } \\
\text { baryte }\end{array}$ \\
\hline Roussillon & $\begin{array}{l}\text { PIG_0173 } \\
(2016-022)\end{array}$ & $\begin{array}{l}\text { More or less corroded quartz } \\
\text { grains }(200-400 \mu \mathrm{m}) \text { in an } \\
\text { iron-rich clayey matrix }\end{array}$ & $\begin{array}{l}\text { Hematite, kaolinite, } \\
\text { quartz, goethite, } \\
\text { zircon }\end{array}$ \\
\hline Beauregard & $\begin{array}{l}\text { PIG_0174 } \\
(2016-023)\end{array}$ & $\begin{array}{l}\text { Entirely ferruginised crinoid } \\
\text { fragments ( } 3 \mathrm{~mm}) \text { in a } \\
\text { hematite-rich cement }\end{array}$ & $\begin{array}{l}\text { Hematite, goethite, } \\
\text { baryte }\end{array}$ \\
\hline Pierrerue & $\begin{array}{l}\text { PIG_0176 } \\
(2016-025)\end{array}$ & $\begin{array}{l}\text { Ferruginous pisoliths visible to } \\
\text { the naked eye, hematite ball in } \\
\text { hexagonal plates ( } 10 \mu \mathrm{m}) \text { and } \\
\text { kaolinite accordions }(<5 \mu \mathrm{m})\end{array}$ & $\begin{array}{l}\text { Kaolinite, hematite, } \\
\text { calcite, goethite, } \\
\text { alumina minerals }\end{array}$ \\
\hline
\end{tabular}

Table 1 : Summarized petrological descriptions, SEM-EDX and XRD results obtained for the standards samples (Major (>20\%), minor, traces - not identified by XRD $(<$ $3 \%)$ but identified with SEM-EDX) 